\title{
Intellectual Capital and Financial Performance: A Meta-Analysis and Research Agenda
}

\author{
Elisabeth Albertini $\bullet$ Fabienne Berger-Remy
}

Accepted by co-editor in chief Thomas Roulet

\begin{abstract}
In the post-industrial economy, intellectual capital (IC) in the form of human, structural or relational capital is becoming a crucial factor for a firm's long-term performance, as it constitutes a competitive advantage from the resource-based theory perspective. Previous research led to a fragmented view of IC, as the relationship between IC and corporate financial performance has been mostly studied mobilizing human, structural or relational capital components in isolation. Furthermore, most studies conclude that even though the relationship is positive, it remains at best unclear. Another unsolved issue lies in value capture-namely, who, among various stakeholders, benefits most from the value created by IC. Using a statistical meta-analysis of 75 empirical studies from 1992 to 2017 , this research shows that human capital (HC), structural capital (SC) and relational capital $(R C)$ do not influence corporate financial performance to the same extent. This can be explained by the characteristics of IC components in term of ownership, tradability and timespan, and the beneficiary of the value created, being the company, the investor or the customer.

This work, then, contributes to an extended view of resource-based theory, mostly by highlighting that some IC components are interrelated in their association with financial performance. Lastly, this research opens new avenues for research in four directions: (1) identification and classification of IC components; (2) understanding of the combination and orchestration of intangible assets; (3) improvement of indicators and measurement systems of IC; and (4) enhancement of the understanding of value creation through narrative means, namely extra-financial disclosure and corporate communication.
\end{abstract}

Keywords: intellectual capital, resource-based theory, financial performance, relational capital, structural capital, human capital, brand equity

\section{INTRODUCTION}

Our contemporary economy is witnessing a historic shift in which value creation no longer comes from the mastery of production but rather from intellectual capital (IC) (Dean \& Kretschmer, 2007; Murthy \& Mouritsen, 2011). This shift is regularly featured in the headlines of the economic press, which praises new business models such as Airbnb and Uber (Pfeffer 2014), which operate with almost no physical capital. Apple, exemplary in the way the company creates value with IC such as design, innovation and brand, may be the most valued brand ever ${ }^{1}$ and yet owns few manufacturing facilities. Paradoxically, intangible assets that have not

\author{
Elisabeth Albertini \\ Sorbonne Business School \\ University of Paris 1 Pantheon- \\ Sorbonne \\ France \\ albertini.iae@univ-paris1.fr \\ Fabienne Berger-Remy \\ Sorbonne Business School \\ University of Paris 1 Pantheon- \\ Sorbonne \\ France \\ berger-remy.iae@univ-paris1.fr
}


been bought are not reported in a company's financial statements, leading to situations where the book value of brands, such as Apple or Hermès, is equal to zero. This insufficiency in the accounting framework keeps IC invisible to managers, making it difficult to adequately allocate financial resources to a specific intangible good (Gowthorpe, 2009).

In this context, IC is becoming a crucial factor for a firm's long-term profit and performance (Crook, Ketchen, Combs \& Todd, 2008; Dean \& Kretschmer, 2007; Mouritsen, 2006). IC is defined as a set of intangible resources and capabilities possessed or controlled by a firm-such as knowledge, culture, brands, reputation, relational network, processes - that create value in the form of competitive advantage. It is an important part of resource-based theory (RBT) and contributes to performance from this theoretical perspective (Barney, Ketchen \& Wright, 2011; Bollen, Vergauwen \& Schnieders, 2005). The value of IC also lies in its intangible nature, which makes it rare and difficult to imitate, in contrast with tangible assets that are easier to buy or to copy (Martin de Castro, Delgado-Verde, Lopez-Saez \& Navas-Lopez, 2011; Ray, Barney \& Muhanna, 2004). Moreover, IC is hard to exchange since it is deeply embedded in the company which controls it (Molloy, Chadwick, Ployhart \& Golden, 2011). Lastly, even if competitors attempt to imitate IC, a high degree of uncertainty remains about the return on investment both in magnitude and in time lag (Juma \& Payne, 2004). In short, there is a relationship between IC and firm performance, but it is at best unclear (Crook, Ketchen, Combs \& Todd, 2008).

Hence, value creation generated by IC presents significant challenges for both researchers and practitioners. According to the academic literature, IC is divided into three main components: human capital $(\mathrm{HC})$ (knowledge, skills, training or innovation), structural capital (SC) (efforts in R\&D, technological infrastructure, organizational culture and values) and relational capital (RC) (relationships with customers, other stakeholders and society as a whole, as well as consumer-brand relationships) (Bontis, 1998; Edvinsson \& Malone, 1997; Martin de Castro et al., 2011). Hence, these components, very different by nature, are interrelated with one another within the company, which in turn provide competitive advantages in line with RBT (Barney et al., 2011; Bollen et al., 2005; Yuqian \& Dayuan, 2015). Then, a significant amount of research has been conducted to demonstrate in isolation the influence of a specific IC component on a firm's corporate financial performance (CFP), measured either by accounting-based or stock market value indicators, or more rarely by both types of ratio. The question may legitimately be asked whether the different IC components contribute equally to a firm's CFP and whether the created value is captured by shareholders through the increase of the stock price or by the managers of the firm through accounting performance.

To sum up, two important issues have not yet been fully covered. The first is related to the typology of IC commonly acknowledged in the literature, where IC components are usually placed on an equal footing. However, it is very likely that, because of their distinct characteristics, they can be compared with regard to their contribution to financial performance. The second issue is linked closely with value appropriation. In the classical view of RBT, possession of IC automatically leads to superior performance for the firm, based on the premise that value creation is harmoniously distributed throughout the different stakeholders. However, empirical research shows that not all value created necessarily flows to the company; for instance, a platform business may fail if value is not equally distributed between consumers, producers and the platform (Van Alstyne,
1. Interbrand. Best global brands ranking 2015. Retrieved from www.interbrand.com 
Parker \& Choudary, 2016). Hence, it is of critical importance for the RBT to question the issue of value appropriation by the company (Crook et al., 2008).

Thus, the objective of this research is to fill those gaps and to determine (1) to what extent each and every IC component contributes to the financial performance of the firm and (2) whether the contribution is captured by managers of the firm, shareholders or customers through accounting-based performance, stock market value or customer performance. In other words, does IC create value for the organization or for the investors and/or the customers? A close examination of empirical findings is therefore critical for furthering knowledge in this area and provides a detailed research agenda.

To answer these questions, we opted for a statistical synthesis (meta-analysis) of 75 studies conducted from 1992 to 2017. Meta-analysis is a statistical technique that aggregates empirical findings to discern whether associations exist and, more importantly, provides estimates of their size (Damanpour, 1991; Grinstein, 2008; Scheer, Miao \& Palmatier, 2015). By statistically aggregating results across individual studies and correcting statistical artifacts, such as sampling and measurement error, meta-analysis allows for much greater precision than other forms of research review (Hunter, Schmidt \& Jackson, 1982). Moreover, metaanalysis can estimate the extent to which the economic value created is revealed differentially in performance measures (Crook et al., 2008). Several meta-analyses have studied in isolation the relationship between business performance and forms of RC such as advertising (Conchar, Crask \& Zinkhan, 2005; Eisend, 2009), customer relationship (Edeling \& Fischer, 2016; Palmatier, Dant, Grewal \& Evans, 2006), customer satisfaction (Orsingher, Valentini \& de Angelis, 2010; Szymanski \& Henard, 2001) and product innovativeness (Szymanski, Kroff \& Troy, 2007). However, to our knowledge, no research has taken a more holistic view of IC.

From a theoretical point of view, this research aims at shedding light on the nature of $\mathrm{IC}$ and its links to financial performance by answering a research call about the potential superiority of certain strategic resources (Crook et al., 2008). This meta-analysis highlights that, unexpectedly, the different IC components-human capital ( $\mathrm{HC})$, structural capital (SC) and relational capital $(\mathrm{RC})-$ do not influence CFP in the same proportion, demonstrating the complex nature of IC. This review opens new avenues for research and enhances managers' understanding of which IC components to focus on.

The remainder of this article is organized as follows. In the next section we review the background literature on the overall relationship between IC and CFP, present the hypotheses of this research and outline the influence of possible moderators. Next, we describe the meta-analysis technique and procedures used in this paper, and the results of the metaanalytic investigation. Finally, we discuss the theoretical and managerial implications of the findings and some limitations, and make recommendations for future research.

\section{LITERATURE REVIEW}

Although fairly young in their development, IC and related topics have recently increased in popularity, in both academic and practitioner circles (Table 1). Indeed recognition of the importance of IC has increased as more and more firms are creating value based on knowledge and other intangible assets rather than tangible assets such as buildings, equipment 
and real estate (Villalonga, 2004). The subject has gained popularity in several academic fields in management, namely in strategic management, marketing, human resources, accounting and finance. As shown below, this has led to a relatively fragmented view, as each discipline has seen IC from its own angle, mostly emphasizing one or other of the IC components, thus compromising overall view and comparison.

From the strategic management perspective, RBT posits that sustained competitive advantage is derived from the rare, valuable, imperfectly imitable and not substitutable resources and capabilities a firm controls (Barney, 1991; Barney et al., 2011; Barney, Wright \& Ketchen, 2001). These resources and capabilities can be viewed as bundles of tangible and intangible assets, including a firm's management skills, its organizational processes and the information and knowledge it controls (Barney et al., 2001). The specific features of IC can explain its significant role in the performance of the firm (Molloy et al., 2011). While tangible assets deteriorate with use, several components of IC, such as employees' skills, may improve with use. Hence, IC is expected to provide benefits for an undefined timeframe as opposed to tangible assets which have expected depreciation (Cohen, 2011). Moreover, IC is a non-rivalrous good, that is, multiple managers can use it simultaneously. Yet, intangible assets are immaterial, which makes them difficult to imitate or to exchange since they often cannot be separated from their owner (Marr \& Moustaghfir, 2005). Indeed, to acquire an IC such as a brand, firms must often acquire the whole organization (Barney, 1999). Moreover, their immateriality leads to inefficient markets (Cohen, 2011). Hence, companies develop IC within the firm through complex social and organizational processes (Winter, 2003), typically making these intangible assets tacit, hard to codify and difficult to imitate, contributing to the firm's superior and sustainable performance (Villalonga, 2004).

In marketing research, strong brands are typically assets that are rare, valuable, imperfectly imitable and not substitutable. Keller (1993) coined this description in his seminal article on brand equity, when he defined consumer-based brand equity (CBBE) as "the differential effect of brand knowledge on consumer response to the marketing of the brand". Interestingly, for Keller this occurs when the consumer makes brand associations that are favourable, strong and unique, a definition that pretty much matches that of Barney (1991) in the RBT. Hence, brand equity corresponds first and foremost to the value attributed to the brand by each consumer, i.e. CBBE defined as "the added value that a brand endows a product with" (Farquhar, 1989). Brand equity is then assessed on the basis of its potential to propose a superior value to the customer than a similar non-branded or competing product (de Chernatony, Riley \& Harris, 1998). From the firm perspective, the capacity of the brand to modify consumer perceptions and behaviours steadily and consistently towards branded products enables brands to develop a unique competitive force (Changeur, 2004). Brands with high equity will then generate "incremental cash flows which accrue to branded products over and above the cash flows which would result from the sales of unbranded products" (Simon \& Sullivan, 1993). Marketing scholars generally see having strong brands as a competitive advantage (Kimbrough et al., 2009). In parallel to the brand equity stream, other marketing scholars have emphasized the value created by the so-called "market orientation", defined as an organizational culture focused on the creation of superior value for customers (Kohli \& Jaworski, 1990; Narver \& Slater, 1990). In that research stream, a marketoriented company will develop specific skills in customer relationship management (Johnson \& Selnes, 2004), which in turn will provide a 
competitive advantage in the form of customer satisfaction and loyalty (Anderson, Fornell \& Lehmann, 1994; Rego, Morgan \& Fornell, 2013). As a result, customer portfolio is a key asset for market-oriented companies and requires careful management (Ryals, 2005).

From the $\mathrm{HC}$ research perspective, knowledge and tacit skills provide individuals with greater cognitive abilities, leading to more productive and efficient activity (Bontis \& Fitz-Enz, 2002). While human resource management (HRM) practices may be imitable, HRM systems and routines may be unique and contribute to the development of specific capital skills (Barney et al., 2001). Indeed, HC can provide a sustained competitive advantage since it involves knowledge stocks, such as hiring well-educated people, and knowledge flows, such as developing a high level of codified and tacit knowledge (Bontis, 1998; Chadwick, 2017; do Rosario-Cabrita \& Bontis, 2008).

From the accounting research perspective, intangible assets are not captured adequately using current financial-reporting systems, either the IFRS or the generally accepted accounting principles (GAAP), because it is difficult to represent them as an historic cost in a transaction-based accounting framework (Barth, 2015). Explicit legal rights, like patents, copyright and possibly brands, are exceptions and these are reported in the balance sheet if they are bought with other assets. Yet, customer relationships, organizational capital (OC), knowledge assets, $\mathrm{HC}$ and other components of IC are so specific that they cannot be evaluated by a market price and so reported in the balance sheet (Penman, 2009). From the finance research perspective, the market value of the firm reflects its intangible assets such as brand, patents, reputation, human and organizational capital even if they are not recognized by domestic accounting standards (Amir, Lev \& Sougiannis, 2003; Lev \& Zambon, 2003). Value relevance studies find that available financial estimates of intangible assets reliably reflect their value, in that these estimates have a significantly positive relation with share price (Barth, 2015). Moreover, these studies underline the relevance of firms' IC as a major driver of growth and competitiveness (Youndt, Subramaniam \& Snell, 2004). Hence, Table 1 gives a summary of the research field relating to IC.

\begin{tabular}{|l|l|l|}
\hline Research field & Main outputs & $\begin{array}{l}\text { Issues for corporate financial } \\
\text { performance }\end{array}$ \\
\hline $\begin{array}{l}\text { Strategy } \\
\text { Resource-based theory: A firm's } \\
\text { resources, particularly intangible } \\
\text { ones, contribute to a sustained } \\
\text { competitive advantage. }\end{array}$ & $\begin{array}{l}\text { These elements of IC are not easily } \\
\text { identified by managers and are therefore } \\
\text { hard to manage. }\end{array}$ \\
\hline Marketing & $\begin{array}{l}\text { Sustainable competitive advantage } \\
\text { originates from the firm's ability to } \\
\text { build long-lasting relationships with an } \\
\text { array of stakeholders, primarily } \\
\text { customers. }\end{array}$ & $\begin{array}{l}\text { Managers focus on how to build strong } \\
\text { brands and impeccable reputation through } \\
\text { efficient communications and state-of-the } \\
\text { art customer care. }\end{array}$ \\
\hline $\begin{array}{l}\text { Human resource } \\
\text { management }\end{array}$ & $\begin{array}{l}\text { Sustainable competitive advantage is } \\
\text { tied to specific HC skills, core } \\
\text { competences and knowledge. }\end{array}$ & $\begin{array}{l}\text { Managers may wonder how to attract, } \\
\text { develop, motivate and retain employees. }\end{array}$ \\
\hline $\begin{array}{l}\text { Accounting and } \\
\text { finance }\end{array}$ & $\begin{array}{l}\text { IC does not consist of separable } \\
\text { assets that can be captured by } \\
\text { conservative accounting rules in a } \\
\text { balance sheet. Yet investors } \\
\text { recognize the critical importance of IC } \\
\text { in the value creation process of a } \\
\text { company. }\end{array}$ & $\begin{array}{l}\text { The financial statement does not } \\
\text { adequately report the IC of a firm. } \\
\text { Information about IC investments is an } \\
\text { important factor in the process of valuing } \\
\text { shares by investors. }\end{array}$ \\
\hline
\end{tabular}

Table 1 - A synthesis of the IC research field 


\section{OVERALL IC AND CFP ASSOCIATION}

In today's post-industrial economy, capital has expanded from the realm of tangibles to intangibles (Dean \& Kretschmer, 2007). In this context, IC is becoming a crucial factor in a firm's long-term profit and performance in a knowledge-based economy (Bollen et al., 2005; Yuqian \& Dayuan, 2015). IC is defined as a set of intangible resources and capabilities possessed or controlled by a firm. The wide range of academic definitions of IC refers to an organization's total capabilities, knowledge capability, culture, strategy, process and professional practices, intellectual property and relational networks that create value in the form of competitive advantages and therefore contribute strongly to the achievement of a firm's objectives (Bollen et al., 2005; Edvinsson \& Malone, 1997; Hsu, Fang \& Fang, 2009; Morgan, 2012; Phusavat, Comepa, Sitko-Lutek \& Ooi, 2011; Reed, Lubatkin \& Srinivasan, 2006; Teece, 2000). The value of IC also lies in its intangibility, which makes it difficult to imitate, in contrast with tangible assets (Martin de Castro et al., 2011; Ray et al., 2004). Hence, we propose the following hypothesis:

H1: The overall association between intellectual capital (IC) and corporate financial performance (CFP) is positive.

\section{DIVING INTO A COMPLEX ASSOCIATION}

The association between IC and CFP reflects a great deal of complexity since CFP can be measured by different approaches and IC embraces components that are very different by nature.

\section{The approaches of corporate financial performance measurement}

In the sample of studies gathered for this meta-analysis, there is a clear focus on financial performance seen as an outcome (dependent variable). This constitutes potentially a limitation, as financial performance could also be seen as an input (Guérard, Langley \& Seidl, 2013; Lechner \& Gudmundsson, 2012). In our sample, CFP is measured by three broad categories of indicators: (1) stock market value (investor returns); (2) accounting-based indicators (accounting returns); and (3) customer metrics (sales, market share and price premium), as shown in Figure 1. 


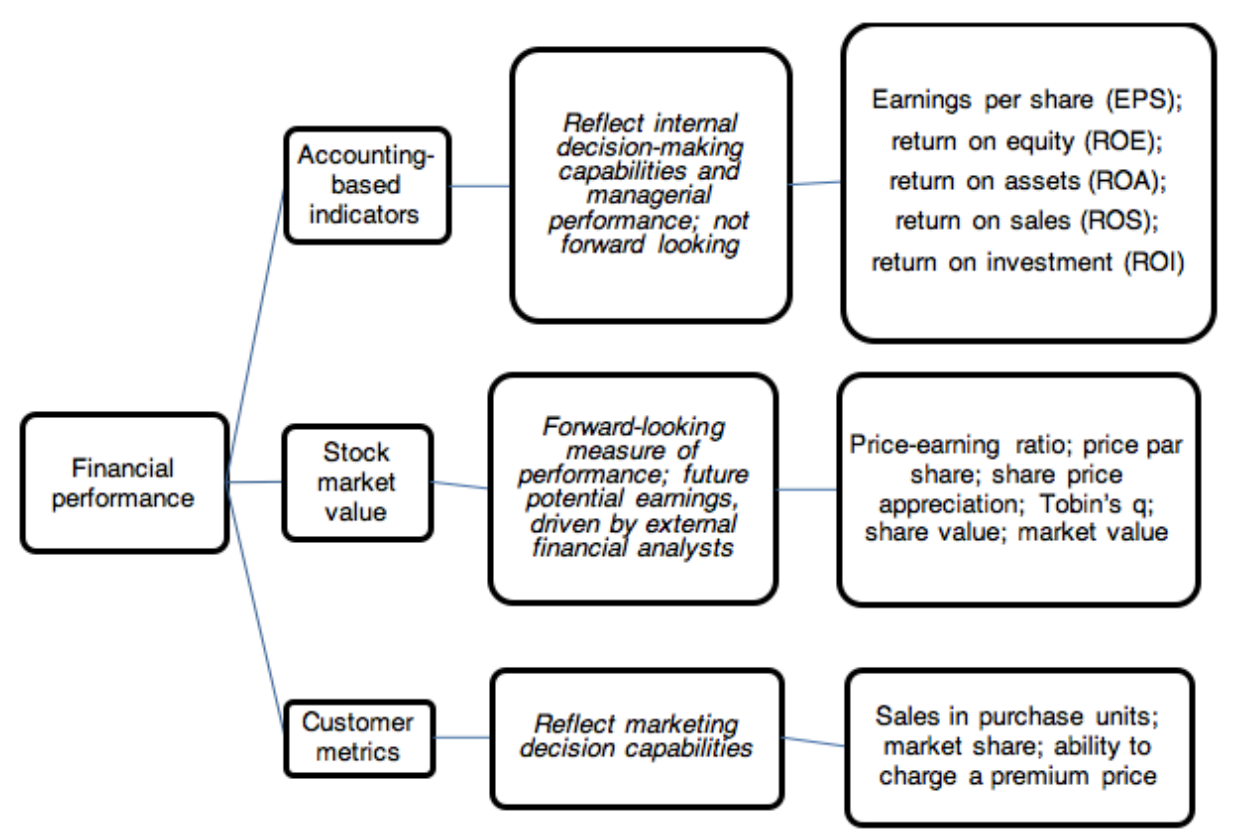

Figure 1. Indicators of corporate financial performance found in the sample studies

Stock market-based indicators (1) often use the price-earnings ratio, price per share or share price appreciation, Tobin's $q$, share value or market value to underscore an improvement in the firm's economic performance. Stock market-based indicators are said to be subject to forces beyond management control. Further, Tobin's $q$ has been extensively used in our sample studies to measure the stock market value of firms because this indicator is a forward-looking measure of performance that captures information about firms' future potential earnings (Bharadwaj, Bharadwaj \& Konsynski, 1999). Indeed, a firm that creates stock market value above the replacement costs of its assets also creates additional firm value. Tobin's $q$ is a surrogate of firm value in the stock market (Matzler, Hinterhuber, Daxer \& Huber, 2005) that has been extensively used as a measure of intangible value (Bharadwaj et al., 1999). Tobin's $q$ reflects the market expectations of less quantifiable dimensions of performance that reflects the portion of the firm's intangible assets in addition to its tangible assets (Lin, Chen \& Wu, 2006).

Accounting-based indicators (2) mainly use earnings per share, return on equity $(\mathrm{ROE})$, return on assets $(\mathrm{ROA})$, return on sales and return on investment (ROI) to measure the financial performance of a firm. ROA and ROE are generally accepted standard measures of financial performance found in strategy research. Accounting-based indicators are subject to managers' discretionary allocations of funds to different IC project choices. These indicators reflect internal decision-making capabilities and managerial performance rather than external market responses to organizational (non-market) actions (Hsu \& Wang, 2012; Phusavat et al., 2011).

In the marketing literature, financial performance can also be estimated using indicators related to customer purchases; for example, a widely used indicator is sales in purchase units (Coviello, Winklhofer \& Hamilton, 2006; Eggers, Kraus, Hughes, Laraway \& Snycerski, 2013; Hooley, Greenley, Cadogan \& Fahy, 2005; Luo, Griffith, Liu \& Shi, 2004; Rubera \& Droge, 2013; Smith \& Wright, 2004; Yeung \& Ennew, 2000) 
followed by other indicators including market share (Hooley et al., 2005; Matsuno, Zhu \& Rice, 2014; Nakao, 1993) and the ability to charge a premium price (Holbrook, 1992; Thomson, Maclnnis \& Park, 2005).

Studies in our sample have adopted a variety of measurements of financial performance. Additionally, in most of the published research, priority is given to one specific component of IC. Attention will now be turned to the composition, or subdivision, of IC into several components as presented in the fields of management science.

\section{The diversity of intellectual capital components}

The academic literature divides IC into three main components (see Figure 2): human capital (HC), structural capital (SC) and relational capital (RC) (Bontis, 1998; Edvinsson \& Malone, 1997; Martin de Castro et al., 2011). HC refers to employees' tacit or explicit knowledge, such as attitudes, experiences, skills, abilities, expertise and know-how. HC leaves the company at night when employees return home and therefore does not fully belong to the company (Chadwick, 2017; Edvinsson \& Malone, 1997). This critical resource helps to differentiate financial performance between firms because HC involves both knowledge stocks (hiring well-educated people) and knowledge flows (developing a high level of codified and tacit knowledge about a specific market and its specific market conditions) (Bontis, 1998). Unlike HC, SC is everything left at the office at night when employees return home. This type of capital corresponds to the institutionalized knowledge and codified experience residing within and used by databases, patents, manuals, structures, systems and processes (Edvinsson \& Malone, 1997; Youndt et al., 2004). SC is composed of the knowledge created by a firm's information technology systems and stored in them, its structure and operating procedure (Edvinsson \& Malone, 1997), and intangible elements such as culture and informational routines (Nelson \& Winter, 1982). Lastly, RC refers to the relationships a firm has with customers, suppliers, partners and social agents who are connected to the organization through its basic business processes, as well as the value of the firm's relations with stakeholders that can be influenced by the firm's activities (Nahapiet \& Ghoshal, 1998). RC is defined as the organization's implicit set of available resources and ongoing relationships implemented through interactions between individuals or organizations (Kostova \& Roth, 2003; Shipilov \& Danis, 2006). These relationships are displayed in Figure 2. 


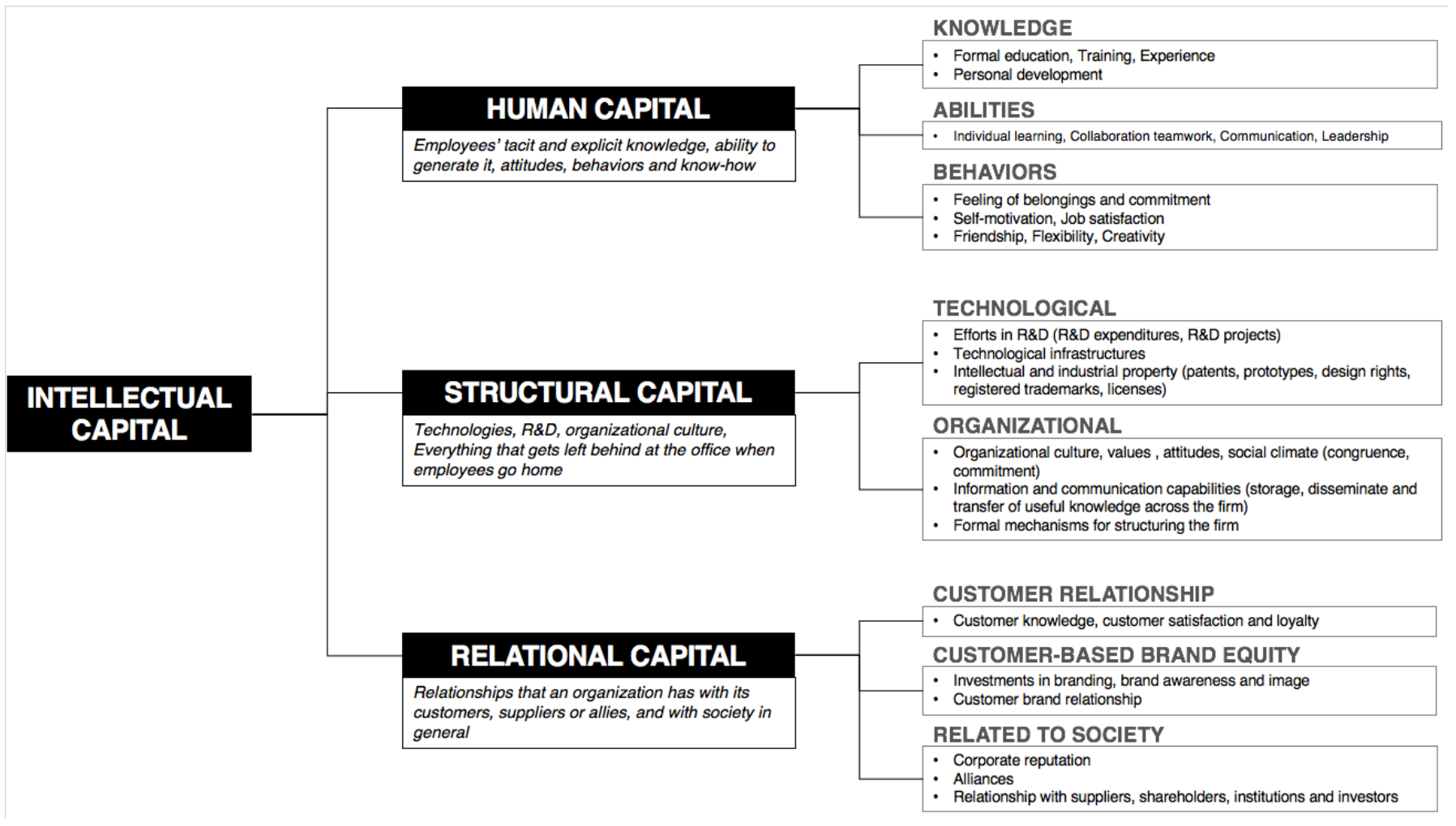

Figure 2. A conceptual view of the components of intellectual capital from Martin de Castro et al. (2011)

\section{HUMAN CAPITAL}

Human capital $(\mathrm{HC})$ is defined as the combined knowledge, skill, innovation and ability of employees (Bontis, Crossan \& Hulland, 2002; Bontis \& Fitz-Enz, 2002). HC, an underlying strategic resource, is both supportive and necessary for success because employees' knowledge and skills are essential in today's fast-paced, rapidly changing competitive climate (Reed et al., 2006; Subramaniam \& Youndt, 2005). Indeed, companies with greater $\mathrm{HC}$ (i.e., higher education, training or skill) are likely to have greater effectiveness and profitability (Aragon-Sanchez, Barba-Aragon \& Sanze-Valle, 2003). As long as HC continues to be developed, staff members can improve their job performance and ultimately improve the firm's performance (Hsu \& Wang, 2012). A firm's HC is an important source of sustained competitive advantage; therefore, investment in the $\mathrm{HC}$ of the workforce may increase employee productivity and financial results (Ling \& Jaw, 2006; Sels et al., 2006). Training has a positive effect on employee productivity and effectiveness in terms of value added by workers (Aragon-Sanchez et al., 2003; Roca-Puig, Beltran-Martin \& Segarra-Copres, 2011). Indeed, trained people develop more efficient means of accomplishing task requirements, thereby increasing productivity (Roca-Puig et al., 2011; Sels et al., 2006). Productivity is directly linked to the share of personal costs in the value added. The lower the latter is, the higher the margin for the company in term of profitability.

It must be highlighted that $\mathrm{HC}$ has barely any impact on stock market value and customer metrics. Indeed, knowledge, abilities or behaviours can only be linked to closer constructs such as productivity or other organizational outcomes (Tharenou, Saks \& Moore, 2007). 
Hence, we hypothesize:

H2: The positive association between human capital (HC) and corporate financial performance (CFP) is stronger when CFP is measured by accounting-based indicators rather than by customer metrics and stock market value.

\section{STRUCTURAL CAPITAL}

Structural Capital (SC) incorporates two sub-components, technological capital (TC) and organizational capital (OC). TC refers to the organizational knowledge directly linked to the development of the activities and functions of the technical system of the organization. The technological system leads to the development of new products and services and to efficient production processes, advancing the organizational knowledge required to develop future technological innovations. This system includes investment in research and development, technological infrastructure and intellectual and industrial property (Edvinsson \& Malone, 1997; Subramaniam \& Youndt, 2005). Conversely, $\mathrm{OC}$ is the combination of explicit and implicit intangible assets that gives organizational cohesion to the different activities and business processes developed in the firm. This type of capital includes organizational culture, values and attitudes, information technology capabilities and the organizational structure of the firm (Martin de Castro et al., 2011). Innovative products generate a large portion of a firm's revenues and, thus, participate to the growth performance of the firm (Cho \& Pucik, 2005). Indeed, investments in research and development pay off significantly in terms of improved productivity and subsequently profitability (Ettlie, 1998). An increase in research and development expenditures generates a positive abnormal stock return since the investors expect that the net present value of future earnings will be enhanced by the new product or the new technology launched by the company (Lin, Lee \& Hung, 2006). Hence, we propose the following hypothesis:

H3: The positive association between structural capital (SC) and corporate financial performance (CFP) is stronger when CFP is measured by accounting-based indicators and stock market value rather than by customer metrics.

\section{RELATIONAL CAPITAL}

Relational capital ( $R C$ ) embraces the relationships of an organization's staff with its clients or customers, suppliers or allies and society in general (Martin de Castro et al., 2011). Stronger relationships foster continuous improvements in new product development through shared knowledge among suppliers, customers and firms (Yarbrough, Morgan \& Vorhies, 2011). Such relationships also secure long-term sales through customer loyalty (Hsu \& Wang, 2012), credibility (Erdem \& Swait, 1998) and superior reputation (Davies, Chun \& Kamins, 2010; Smith, Smith \& Kun, 2010). The marketing literature also focuses on customerbrand relationships (Fournier, 1998) as an advantage for firms. Building strong brands results in customer-based brand equity (CBBE) (Keller, 1993). CBBE is a source of financial value for a firm through the relationship that links consumers with its brand (Thomson et al., 2005). Notably, RC can also theoretically embrace a firm's relationship with society as a whole, acting as an economic agent that plays an active, 
positive role in the social scene. This dialogue with society can in turn provide competitive advantage to the firm in the form of an enhanced reputation, more efficient lobbying policies or easier access to valuable market knowledge.

$\mathrm{RC}$ provides a competitive advantage essentially through a stronger relationship with customers, either directly or through the mediation of brands. The ability to build such relationships is fairly difficult for accountants to appreciate (Gowthorpe, 2009). Notably, recent studies suggest that consumers are able to recognize value in brands above and beyond managers themselves (Berthon, Holbrook, Hulbert \& Pitt, 2007; Diamond et al., 2009; McEnally \& De Chernatony, 1999). Hence, we can posit that $R C$ is presumably more valued by consumers than by accountants (Smith \& Wright, 2004; Yeung \& Ennew, 2000). Indeed, when examining the RC stream of research, new performance indicators emerge about customer metrics, such as essential buying behaviour as a proxy for the amount of sales. These metrics have been used extensively to measure the consequences for CFP of different strategies towards customer relationships (Gupta \& Zeithaml, 2006; Reed et al., 2006; Yeung \& Ennew, 2000). Notably, customer metrics most frequently report intention to buy rather than actual purchases, which constitutes a limitation because the link between attitude and behaviour remains controversial (Gupta \& Zeithaml, 2006). Customer metrics have been approximated by a higher preference rate (Erdem \& Swait, 1998; Park \& Srinivasan, 1994; Shankar, Azar \& Fuller, 2008) or through the propensity to pay a premium price (Holbrook, 1992; Park \& Srinivasan, 1994; Thomson et al., 2005).

Moreover, numerous surveys have reported a positive effect of RC on stock-market value. Brand equity has proven to be an essential component of firm value (Barth, Clement, Foster \& Kasznik, 1998; Kirk, Ray \& Wilson, 2013; Mizik \& Jacobson, 2008, 2009) sustained by the number of brands (Morgan \& Rego, 2009) and advertising expenses (Bharadwaj et al., 1999; Heiens, Leach \& McGrath, 2007; McAlister, Srinivasan \& Kim, 2007; Ohnemus, 2009). Similarly, a positive link between stock market value indicators and customer relationships has been established, measured by customer retention (Livne, Simpson \& Talmor, 2011) and customer satisfaction (Matzler et al., 2005; O'Sullivan \& McCallig, 2012). Lastly, recent research suggests that customer-oriented marketing capabilities have a positive impact on stock market value as measured by Tobin's $q$ (Angulo-Ruiz, Donthu, Prior \& Rialp, 2014). We therefore propose the following hypotheses:

H4: The positive association between relational capital (RC) and corporate financial performance (CFP) is stronger when CFP is measured by customer metrics and stock market value rather than by accounting-based indicators.

\section{METHODOLOGY}

Meta-analysis is a set of statistical techniques developed to identify and quantify associations drawn from an existing body of literature and has been frequently applied to the management literature (Dalton, Daily, Certo \& Roengpitya, 2003; Edeling \& Fischer, 2016; Eisend, 2009; Orlitzky, Schmidt \& Rynes, 2003; Orsingher et al., 2010; Scheer et al., 2015; Szymanski \& Henard, 2001). This quantitative method allows a rigorous integration of the findings of previous studies on a particular topic to assess the overall effect of existing studies and to evaluate the effect of 
different data characteristics on results (Hunter et al., 1982; Rosenthal, 1991; Stanley, 2001; Wolf, 1986).

Meta-analysis involves statistical analyses that reveal associations that are less obvious in other approaches used to summarize research. This technique determines whether differences in results are based primarily on differences in research setting, measurement scale, CFP or IC components, or sampling error.

Consequently, this research method is appropriate to investigate the association between IC and CFP because it will (a) calculate an estimate of the mean effect size for this hypothesized association on the basis of all available prior studies; (b) test for the significance and generalizability of the discovered mean effect size by calculating its confidence interval; (c) assess whether there is heterogeneity in the effect size distribution and whether heterogeneity is found; and (d) investigate and model this heterogeneity through further moderator analyses (Hedges \& Olkin, 1985; Lipsey \& Wilson, 2001).

\section{SAMPLE AND CODING}

To construct a comprehensive database, computer searches were conducted using different combinations of keywords ${ }^{2}$ in the ScienceDirect, EJS Ebsco, EconLit, JSTOR, Emerald, SSRN, AoM and Cairn databases. Rigorous manual searches were also performed to identify additional articles using the reference lists of each study collected. We also consulted major academic journals that publish this type of research 3 .

To be included in this meta-analysis, econometric studies had to provide a statistical measure of the association between IC and financial performance. Meta-analysis requires statistically independent samples (Cheung \& Chan, 2004; Hunter \& Schmidt, 2004). As a result, studies based on the same data set were excluded from this meta-analysis to avoid an over-representation bias. Our meta-analysis also excluded studies with insufficient data to calculate a common measure of effect size and studies that used very different statistical research methods, such as results from logit or probit regression or multivariate analysis (Doucouliagos \& Laroche, 2003; Hunter \& Schmidt, 2004). Out of the initial sample of 153 studies retrieved from the database search, 78 studies were excluded based on these criteria.

The final sample includes a total of 75 empirical studies published from 1992 to 2017, with 120 effect sizes that explored the association between IC and CFP with a combined $N$ size of 78,858 . Data coding focused on several sample and design characteristics, including the date of observation study, country, industrial context, IC component indicators and CFP indicators. Appendix $A$ lists the proxies used by the studies in this meta-analysis. The principal unit of analysis in meta-analysis is the individual study (Hedges \& Olkin, 1985). Since certain studies contain measurements of several sub-components and certain studies report associations with several CFP indicators, the total number of effect sizes exceeds the number of studies.

Two distinct methodological approaches can be taken to address multiple measurements within studies: either we consider the $k$ number of studied relationships in the study as independent or we represent each study by a single value. This research follows the first method, building on the research using the Monte Carlo method, which suggests that meta-
2. Intellectual capital, intangible asset, human capital, goodwill, trademarks, research and development, innovativeness, customer capital, market capital, customer relationship, customer loyalty, brand equity, corporate reputation, customer satisfaction, brand values, market share, market orientation, brand image, customer-brand relationship, financial performance, business performance, price premium, profit, market value, market-tobook value, capital market, return on assets, return on equity, return on sales, profitability, business performance.

3. Including Academy of Management Journal, Journal of Management, Strategic Management Journal, Journal of Management Studies, Marketing Science, Journal of Marketing, Journal of the Academy of Marketing Science, Journal of Marketing Research, International Journal of Research in Marketing, Journal of Business Research, Accounting Review, Journal of Accounting Research and Review of Accounting Studies. 
analytical procedures using a detailed set of measures from each study outperform single-value approaches (Bijmolt \& Pieters, 2001). Specifically, single-value approaches may produce conservative results and underestimate the degree of generalizability across studies (Hunter \& Schmidt, 2004). Consequently, we extracted information from the 75 studies on the 120 effect sizes, sample sizes and moderator variables.

\section{META-ANALYTIC PROCEDURES}

This meta-analysis uses Hunter and Schmidt's (1990) statistical aggregation techniques for cumulating correlations and correcting for various study artifacts to estimate the common measure of effect size between IC and CFP. In the meta-analysis literature, the term effect size is used to denote the magnitude of the relationship between the dependent variable (e.g., CFP) and a specific independent variable (e.g., IC, HC, SC, $\mathrm{TC}, \mathrm{OC}, \mathrm{RC}$, customer relationship capital, CBBE). In this study, the $r$ statistic is calculated to determine the effect size for each pair of variables from each study. Whenever a study reported the $r$ statistic, that is, a coefficient of correlation between IC and CFP, it was used as a measure of effect size. When the $r$ statistic was not reported but other statistics transformable into the $r$ statistic were presented, we used formulas given by Rosenthal (1991) or Wolf (1986) to transform t-test and Z-test into an $r$ statistic. Following Hunter and Schmidt (1990), for each association between IC and CFP, we first calculated the weighted mean correlation coefficient $\left(r^{-}=\sum N_{i} r_{i i} / \sum N_{i}\right)$, the total observed variance $\left(S_{r}^{2}=\sum N_{i}\left(r_{i}-r^{-}\right)^{2} / \sum N_{i}\right)$ and the sampling error variance $\left(S_{e}^{2}=\left(1-r^{-2}\right)^{2} k / \sum N_{i}\right)$, where $N_{i}$ is the number of observations in each sample, $r$ the effect size for sample $i$, and $k$ the number of effect sizes.

While meta-analysis corrects for various statistical artifacts, this statistical technique for research synthesis also allows the aggregation of results across separate studies and yields an estimate of the true relationship between two variables in a population. The zero-order correlations between the variables of interest that a study reports are weighted by the sample size of the study to calculate the mean weighted correlation across all the studies in the analysis. The standard deviation of the observed correlations is then calculated to estimate their variability. Total variability across studies is composed of the true population variation, variation caused by sampling error, and variation linked to other artifacts (that is, reliability and range restriction). Controlling these artifacts provides a more accurate estimate of true variability. To control for such artifacts, we relied on Comprehensive Meta-Analysis (Borenstein, 1997), a software package that employs Hunter and Schmidt's (1990) artifact distribution formulas used in previous meta-analyses in the management field (Certo, Lester, Dalton \& Dalton, 2006; Dalton et al., 2003; King, Dalton, Daily \& Covin, 2004).

Confidence intervals were calculated with corrected standard deviation estimates and the standard errors of the mean-corrected effect sizes established (Whitener, 1990). Confidence intervals provide information on the reliability of the estimate of the weighted mean coefficient correlation by stating the range of values between which the true value of this value is likely to lie, given a self-chosen confidence level (in our case, 95\%). Hence, a 95\% confidence interval that does not include zero indicates that there is a true relationship between the variables of interest (Hunter \& Schmidt, 1990). 
Following Hunter \& Schmidt's procedures (Hunter \& Schmidt, 1990), our meta-analysis uses the percentage of observed variance across studies to test heterogeneity rather than the credibility interval. The $Q$ and 12 statistics empirically confirm the theoretical assumption of sample heterogeneity (Huedo-Medina, Sanchez-Meca, Marin-Martinez \& Botella, 2006). While, the Q-statistic has been criticized because of its excessive power to detect unimportant heterogeneity when there are many studies (Higgins \& Thompson, 2002), the $R^{2}$ index is more informative since it quantifies the proportion of between-study variance due to heterogeneity regardless of the number of studies. Indeed, the $l 2$ index can be interpreted as the percentage of the total variability in a set of effect size due to true heterogeneity, that is, between-studies variability (Huedo-Medina et al., 2006). In that context, an $l^{2}$ of $75 \%$ indicates large heterogeneity; $50 \%$, moderate heterogeneity; and $25 \%$, low heterogeneity (Higgins \& Thompson, 2002).

We conducted moderator analyses by separating the sample into relevant subgroups with meta-analyses performed on each subgroup. This hierarchical subgroup method, advocated by Hunter and Schmidt (1990), assesses the heterogeneity of the sample. Using this method, studies are separated into subgroups according to theoretically predicted moderators. This subgrouping is hierarchical, allowing moderators to "nest" within each other and therefore be considered in combination (Steel \& KammeyerMueller, 2002). The purpose of subgrouping is to reduce heterogeneity and increase explanatory power. Earlier meta-analyses suggest that studies can be classified according to differences in the measurement of the dependent and explanatory variables to reduce the level of variance in results (Steel \& Kammeyer-Mueller, 2002).

In the overall meta-analysis, we performed an effect size "file drawer analysis" to address the possibility of publication bias, which occurs when published studies report larger and more positive effect sizes than unpublished studies. File drawer analysis addresses this issue by calculating the number of additional unknown studies required to widen the reported confidence interval enough to include zero (Hunter \& Schmidt, 1990; Rosenthal, 1978). Thus, the file drawer can be interpreted as an indication of the stability of the relationship.

\section{FINDINGS}

Using the meta-analytical techniques described above, we examined the association between IC and CFP (Table 2) and the moderators' influence on this association (Table 3).

\begin{tabular}{|c|c|c|c|c|c|c|c|c|c|c|c|c|}
\hline & \multicolumn{5}{|c|}{ Effect size and $95 \%$ confidence interval } & \multicolumn{3}{|c|}{ Test of null } & \multicolumn{4}{|c|}{ Heterogeneity } \\
\hline & $k$ & $N$ & Mean & $\begin{array}{c}\text { Lower } \\
\text { limit }\end{array}$ & $\begin{array}{l}\text { Upper } \\
\text { limit }\end{array}$ & $\begin{array}{c}Z \\
\text { score }\end{array}$ & $p$ & $Q$ value & $\mathrm{df}(\mathrm{Q})$ & $p$ & $1^{2}$ & $\begin{array}{l}\text { File } \\
\text { drawer }\end{array}$ \\
\hline $\begin{array}{l}\text { Fixed effect } \\
\text { model }\end{array}$ & 120 & 78,858 & 15 & 8 & 22 & 4,294 & $<0.000$ & $3,782.91$ & 119 & $<0.000$ & 96.85 & \\
\hline $\begin{array}{l}\text { Rando } \\
\text { effect model }\end{array}$ & 120 & 78,858 & 146 & 105 & 186 & 6,950 & $<0.000$ & 0.17 & & & 0.88 & 4,681 \\
\hline
\end{tabular}

Note: $\mathrm{k}=$ number of independent effect-size meta-analysed; $\mathrm{N}=\mathrm{N}=$ total sample size across all estimate; Mean = weighted Note: $\mathrm{k}=$ number of independent effect-size meta-analysed; $\mathrm{N}=N=$ total sample size across all estimate; Mean $=$ weighted
mean effect size; $\mathrm{Cfl} 95 \%=$ lower and upper bound of $95 \%$ confidence interval for mean; $\mathrm{Z}$ score: standard deviation; $p=$ probability at $95 \% ; Q$ value $=$ value of chi-square distributed homogeneity statistic $Q ; 12$ : I squared = percentage of total
variation across studies due to heterogeneity, File drawer = number of missing studies averaging null findings needed to variation across studies due to heterogeneity, File draw 0 ,
bring the sample-size weighted mean observed down to 0.

Table 2 - Overall meta-analytic findings between IC and CFP 


\begin{tabular}{|c|c|c|c|c|}
\hline Moderators & $\begin{array}{l}\text { Accounting-based } \\
\text { indicators }\end{array}$ & Customer metrics & Stock market value & Overall financial performance \\
\hline Human capital & $\begin{array}{l}\text { Mean: } 0.162 \\
\text { Cfi } 95 \%: 0.133 / 0.191 \\
\text { k: studies; } 13 \\
\text { N: } 4,377 \\
\text { SE: } 0.011 ; p=0,000\end{array}$ & $\begin{array}{l}\text { Mean: } 0.105 \\
\text { Cfi } 95 \%:-0.162 / 0.358 \\
\text { k:1 study; } \\
\text { N: } 53 \\
\text { SE: } 0.000 ; p: 0,443\end{array}$ & 0 study & $\begin{array}{l}\text { Mean: } 0.162 \\
\text { Cfi } 95 \%: 0.133 / 0.190 \\
\text { k:14 studies; } \\
N: 4,430 \\
\text { SE: } 0.011 ; p=0,000\end{array}$ \\
\hline Structural capital & $\begin{array}{l}\text { Mean: } 0.073 \\
\text { Cfi } 95 \%: 0.048 / 0.097 \\
\text { k: } 22 \text { studies; } \\
\text { N: } 6,552 \\
\text { SE: } 0.025 ; p=0,000\end{array}$ & $\begin{array}{l}\text { Mean: } 0.066 \\
\text { Cfi } 95 \%:-0.010 / 0.142 \\
k: 4 \text { studies; } \\
\text { N: } 654 \\
\text { SE: } 0.047 ; p=0,089\end{array}$ & $\begin{array}{l}\text { Mean: } 0.063 \\
\text { Cfi } 95 \%: 0.037 / 0.089 \\
k: 12 \text { studies; } \\
\text { N: } 5,574 \\
\text { SE: } 0.035 ; p=0,000\end{array}$ & $\begin{array}{l}\text { Mean: } 0.068 \\
\text { Cfi } 95 \%: 0.051 / 0.085 \\
k: 38 \text { studies; } \\
\text { N: } 12,780 \\
\text { SE: } 0.018 ; p=0,000\end{array}$ \\
\hline $\begin{array}{l}\text { - Technological } \\
\text { capital }\end{array}$ & $\begin{array}{l}\text { Mean: } 0.027 \\
\text { Cfi } 95 \%:-0.002 / 0.055 \\
\text { k: } 11 \text { studies; } \\
\text { N: } 4,709 \\
\text { SE: } 0.045 ; p=0,066\end{array}$ & $\begin{array}{l}\text { Mean: } 0.066 \\
\text { Cfi } 95 \%:-0.01 / 0.142 \\
\text { k: } 4 \text { studies; } \\
\text { N: } 654 \\
\text { SE: } 0.047 ; p=0,089\end{array}$ & $\begin{array}{l}\text { Mean: } 0.058 \\
\text { Cfi } 95 \%: 0.032 / 0.085 \\
\text { k: } 11 \text { studies; } \\
\text { N: } 5,476 \\
\text { SE: } 0.035 ; p=0,000\end{array}$ & $\begin{array}{l}\text { Mean: } 0.045 \\
\text { Cfi } 95 \%: 0.026 / 0.064 \\
k: 26 \text { studies; } \\
\text { N: } 10,839 \\
\text { SE: } 0.023 ; p=0,000\end{array}$ \\
\hline $\begin{array}{l}\text {-Organizational } \\
\text { capital }\end{array}$ & $\begin{array}{l}\text { Mean: } 0.188 \\
\text { Cfi } 95 \%: 0.143 / 0.231 \\
\text { k: } 11 \text { studies; } \\
\text { N: } 1,843 \\
\text { SE: } 0.008 ; p=0,000\end{array}$ & 0 studies & $\begin{array}{l}\text { Mean: } 0.326 \\
\text { Cfi } 95 \%: 0.139 / 0.490 \\
\text { k: } 1 \text { study; } \\
\text { N: } 98 \\
\text { SE: } 0.000 ; p=0,001\end{array}$ & $\begin{array}{l}\text { Mean: } 0.195 \\
\text { Cfi } 95 \%: 0.152 / 0.237 \\
\text { k: } 12 \text { studies; } \\
\text { N: } 1,941 \\
\text { SE: } 0.007, p=0,000\end{array}$ \\
\hline Relational capital & $\begin{array}{l}\text { Mean: }-0.076 \\
\text { Cfi } 95 \%:-0.087 /-0.066 \\
k: 26 \text { studies; } \\
\text { N: } 32,841 \\
\text { SE: } 0.044 ; p=0,000\end{array}$ & $\begin{array}{l}\text { Mean: } 0.086 \\
\text { Cfi } 95 \%: 0.063 / 0.108 \\
k: 16 \text { studies; } \\
\text { N: } 7,714 \\
\text { SE: } 0.021 ; p=0,000\end{array}$ & $\begin{array}{l}\text { Mean: } 0.061 \\
\text { Cfi } 95 \%: 0.047 / 0.074 \\
\text { k: } 22 \text { studies; } \\
\text { N: } 19,999 \\
\text { SE: } 0.003 ; p=0,000\end{array}$ & $\begin{array}{l}\text { Mean: }-0.010 \\
\text { Cfi } 95 \%:-0.018 /-0.003 \\
k: 64 \text { studies; } \\
\text { N: } 60,554 \\
\text { SE: } 0.018 ; p=0,010\end{array}$ \\
\hline $\begin{array}{l}\text { •Customer } \\
\text { relationship }\end{array}$ & $\begin{array}{l}\text { Mean: } 0.105 \\
\text { Cfi } 95 \%: 0.086 / 0.124 \\
\text { k: } 17 \text { studies; } \\
\text { N: } 10,319 \\
\text { SE: } 0.012 ; p=0,000\end{array}$ & $\begin{array}{l}\text { Mean: } 0.106 \\
\text { Cfi } 95 \%: 0.076 / 0.136 \\
\text { k: } 9 \text { studies; } \\
\text { N: } 4,148 \\
\text { SE: } 0.019 ; p=0,000\end{array}$ & $\begin{array}{l}\text { Mean: } 0.169 \\
\text { Cfi } 95 \%: 0.129 / 0.207 \\
\text { k: } 6 \text { studies; } \\
\text { N: } 2,394 \\
\text { SE: } 0.003 ; p=0,000\end{array}$ & $\begin{array}{l}\text { Mean: } 0.114 \\
\text { Cfi } 95 \%: 0.099 / 0.129 \\
\text { k: } 32 \text { studies; } \\
\text { N: } 16,861 \\
\text { SE: } 0.008 ; p=0,000\end{array}$ \\
\hline $\begin{array}{l}\text {-Customer-based } \\
\text { brand equity }\end{array}$ & $\begin{array}{l}\text { Mean: }-0.158 \\
\text { Cfi } 95 \%:-0.171 /-0.146 \\
\text { k: } 9 \text { studies; } \\
\text { N: } 22,522 \\
\text { SE: } 0.073 ; p=0,000\end{array}$ & $\begin{array}{l}\text { Mean: } 0.062 \\
\text { Cfi } 95 \%: 0.029 / 0.095 \\
\text { k: } 7 \text { studies; } \\
\text { N: } 3,566 \\
\text { SE: } 0.059 ; p=0,000\end{array}$ & $\begin{array}{l}\text { Mean: } 0.048 \\
\text { Cfi } 95 \%: 0.033 / 0.062 \\
\text { k: } 17 \text { studies; } \\
\text { N: } 18,049 \\
\text { SE: } 0.002 ; p=0,000\end{array}$ & $\begin{array}{l}\text { Mean: }-0.057 \\
\text { Cfi } 95 \%:-0.066 /-0.048 \\
\text { k: } 33 \text { studies; } \\
\text { N: } 44,137 \\
\text { SE: } 0.026 ; p=0,000\end{array}$ \\
\hline Intellectual capital & $\begin{array}{l}\text { Mean: }-0.026 \\
\text { Cfi } 95 \%:-0.035 /-0.017 \\
k: 63 \text { studies; } \\
\text { N: } 44,321 \\
\text { SE: } 0.029 ; p=0,000\end{array}$ & $\begin{array}{l}\text { Mean: } 0.084 \\
\text { Cfi } 95 \%: 0,063 / 0.105 \\
k: 21 \text { studies; } \\
\text { N: } 8,421 \\
\text { SE: } 0.019 ; p=0,000\end{array}$ & $\begin{array}{l}\text { Mean: } 0.063 \\
\text { Cfi } 95 \%: 0.051 / 0.075 \\
k: 36 \text { studies; } \\
\text { N: } 26,116 \\
\text { SE: } 0.006 ; p=0,000\end{array}$ & $\begin{array}{l}\text { Mean: } 0.015 \\
\text { Cfi } 95 \%: 0.008 / 0.022 \\
k: 120 \text { studies; } \\
\text { N: } 78,858 \\
\text { SE: } 0.014 ; p=0,000\end{array}$ \\
\hline
\end{tabular}

Note: for each analysis, $k=$ number of independent effect sizes meta-analysed by subgrouping the studies; $N=$ total sample size across all estimate; Mean = weighted mean effect size; Cfl $95 \%=$ lower and upper bound of $95 \%$ confidence interval for mean; SE: standard error; $p=$ probability at $95 \%$.

Table 3 - Meta-analysis moderators' results (fixed-effect model)

Table 2 summarizes the results of the meta-analysis of the overall association between IC and CFP. Table 3 presents the results of the moderator's analysis detailing the association between each IC component and each CFP measure. In each table, the weighted mean effect size (Mean) shows the magnitude of the different studied associations between financial performance and IC, while confidence intervals provide information about the reliability of this estimated weight-mean effect-size.

As shown in Table 2, the mean correlation of the association between IC and CFP is positive (0.015 with a $95 \%$ confidence interval of $0.008 / 0.022$ ) for the total set of 120 effect sizes and a total sample size $N$ of 78,858 observations when using the conservative fixed-effect model. This finding holds for all different measures of IC and all different measures of CFP for all the studies included in this meta-analysis. The associated confidence interval is small and does not include zero, providing evidence 
of a significant positive association between IC and CFP and thus supporting $\mathrm{H} 1$. As shown in Table 2, 4,681 additional studies are necessary to change the overall substantive conclusions of this meta-analysis. A closer look reveals that among the three categories of CFP variables, the association between IC and CFP measured by accounting-based indicators is negative ( -0.026 with a $95 \%$ confidence interval of $-0.035 /-0.017)$. This result highlights the difficulties that the accounting framework has to measure the value creation generated by IC. Moreover, most of the IC expenditures are registered as expenses impacting the annual profit of the company and thus are not considered as investments. Specifically, the positive association between IC and CFP is stronger when CFP is measured by customer metrics ( 0.084 with a $95 \%$ confidence of $0.063 / 0.105)$ than measured by stock market value $(0.063$ with a $95 \%$ confidence interval of $0.051 / 0.075)$. Yet, these two confidence intervals overlap, leading us to conclude that there is no significant difference between customer metrics and stock market value as an outcome of the IC when looking at the association between IC and CFP. In other words, the positive association between IC and customer metrics or IC and stock market value could have some common values. Hence there is a positive association between IC and CFP, measured by both customer metrics and stock market value.

For the overall meta-analysis results, the $l 2$ index is $96.85 \%$, supporting the existence of moderators of the association between IC and CFP. Hence, we have conducted a moderator analysis of the association between the different IC components and CFP.

As shown in Table 3, the overall link between $\mathrm{HC}$ and CFP is positive (0.162 with a $95 \%$ confidence interval of $0.133 / 0.190)$. Furthermore, the positive HC-CFP association is stronger when CFP is measured by accounting-based indicators rather than by customer metrics, supporting H2. Moreover, this confidence interval does not include zero, suggesting that this mean effect size is truly positive. It is worth noting here that $\mathrm{HC}$ is the component of IC that has been less studied. An explanation for this may be that independent explanatory variables measuring $\mathrm{HC}$ may be quite distant from financial performance-in other words, direct effects could be very difficult to prove, because $\mathrm{HC}$ is entangled with a myriad of other factors.

Similarly, the link between SC and CFP is positive $(0.068$ with a $95 \%$ confidence interval of $0.051 / 0.085)$. This last confidence interval is relatively narrow and does not include zero, suggesting that the estimate is fairly precise and truly positive. More importantly, the positive SC-CFP association is stronger when CFP is measured by accounting-based indicators $(0,073$ with a confidence interval of $0,048 / 0,097)$ and measured by stock market value $(0,063$ with a confidence interval of $0,037 / 0,089)$ rather than by customer metrics $(0,066$ with a confidence interval of $-0,010 / 0,142)$. The confidence intervals of the first two associations overlap leading us to conclude that the SC influence CFP measured by bothaccounting-based indicators and stock market value-supporting $\mathrm{H} 3$.

When delving into the details by splitting the $\mathrm{SC}$, the results show that the positive association between OC and CFP is stronger ( 0.195 with a $95 \%$ confidence interval of $0.152 / 0.237)$ than between TC and CFP $(0.045$ with a $95 \%$ confidence interval of $0.026 / 0.064)$. Indeed, research suggests that organizations' operational processes and the commitment of sufficient resources have an important impact on performance (Hsu \& Wang, 2012). OC such as operations, procedures and the processes of knowledge management have a positive effect on performance because organizations are increasingly employing advanced technologies to compete in today's 
economy (do Rosario-Cabrita \& Bontis, 2008; Reed et al., 2006). The link between TC and CFP is stronger when CFP is measured by stock market value (0.058 with a $95 \%$ confidence interval of $0.032 / 0.085)$. The innovative propensity of a firm positively influences the degree to which above-average profits persist over time (Artz, Norman, Hatfield \& Cardinal, 2010; Coombs \& Bierly, 2006). Firms' R\&D investments generate persistent profits, high stock returns and superior market value (McAlister et al., 2007), which give clearly positive signals to investors. Then, the association between TC and CFP measured by accounting-based indicators (0.027) or customer metrics (0.066) is positive, yet the $95 \%$ confidence intervals of these last two results include zero, leading us to conclude that these associations are not clearly positive. These results may be explained by the time horizon, as consumers may value innovativeness much later, when R\&D investments are translated into new products and services. The same applies to accountants, as R\&D investments are not necessarily amortized, and therefore may decrease operating profit short term.

Lastly, our findings show that the positive RC-CFP association is stronger when CFP is measured by customer metrics (0,086 with a $95 \%$ confidence interval of $0,063 / 0,108)$ or stock market value $(0,061$ with a confidence interval of $0,047 / 0,074$ ) rather than by accounting-based indicators. The confidence intervals of the first two associations overlap, leading us to conclude that $\mathrm{RC}$ is positively associated with CFP measured by both customer metrics and stock market value, supporting $\mathrm{H} 4$.

Then, more surprisingly, the overall association between RC and CFP is negative $(-0.010$ with a $95 \%$ confidence interval of $-0.018 /-0.003)$. Indeed, the association between RC and CFP is negative when measured by accounting-based indicators (-0.076 with a 95\% confidence interval of $-0.087 /-0.066)$, whereas the association remains positive when measured by stock market value $(0.061)$ or customer metrics $(0.086)$. To gain more understanding on this result, a closer look was taken on the subcomponents of the RC. What came out is that the association between CBBE and financial performance is negative (-0.057 with a 95\% confidence interval of $-0.066 /-0.048)$, whereas the link between customer relationship capital and CFP is positive ( 0.114 with a $95 \%$ confidence interval of 0.099/0.129). This interval does not include zero, indicating that the mean effect size is clearly positive. Because the $95 \%$ confidence interval of the two sets of studies does not overlap, we can conclude that the different $\mathrm{RC}$ sub-components are significant moderators in the association between $\mathrm{RC}$ and CFP.

When subjected to closer scrutiny, it was apparent that this negative association came from brand equity when measured by accounting-based indicators $(-0.158$ with a $95 \%$ confidence interval of $-0.171 /-0.146)$. However, the association remains positive when CFP is measured using stock market value $(0.048$ with a $95 \%$ confidence interval of $0.033 / 0.062)$ or customer metrics ( 0.062 with a $95 \%$ confidence interval of $0.029 / 0.095)$. The confidence intervals do not include zero, indicating that the mean effect sizes are truly positive for the last two associations. The confidence intervals of the association between brand equity and CFP measured by customer metrics and by stock market value overlap, leading us to conclude that there is a positive association between brand equity and CFP measured by these two kinds of performance. It appears then that CBBE constitutes a source of financial value for a firm through the relationship that ties consumers to a particular brand (Thomson et al., 2005). Investors evaluate this relationship "power" of brands as a promise of future earnings (Barth, et al., 1998; Madden, Fehle \& Fournier, 2006). 
There should be future discussion about why accountants do not appreciate this asset to the same extent.

Finally, the positive association between Customer Relationship and CFP is weaker when measured by accounting-based indicators ( 0.105 with a $95 \%$ confidence interval of $0.086 / 0.124$ ) than when measured by stock market value $(0.169$ with a $95 \%$ confidence interval of $0.129 / 0.207)$ or customer metrics (0.106 with a $95 \%$ confidence interval of $0.076 / 0.136)$. Nevertheless, because the confidence intervals overlap for the three sets of studies (customer relationship with accounting-based indicators, with customer metrics, with stock market value), we cannot conclude that these associations are statistically different but rather that there is a positive association between customer relationship and CFP however this performance is measured. Additional studies are needed to examine the impact of customer relationship on CFP to clearly establish where the value creation lies. These findings are summarized in Table 4.

\begin{tabular}{|c|c|c|c|c|}
\hline Hypothesis & $\begin{array}{l}\text { IC or IC } \\
\text { components }\end{array}$ & $\begin{array}{l}\text { Corporate } \\
\text { financial } \\
\text { performance }\end{array}$ & Association & Findings \\
\hline $\mathrm{H} 1$ & IC & CFP & $\begin{array}{l}\text { Positive } \\
\text { The association is stronger when } \\
\text { measured by customer metrics }\end{array}$ & Supported \\
\hline $\mathrm{H} 2$ & $\mathrm{HC}$ & $\begin{array}{l}\text { CFP measured by } \\
\text { accounting-based } \\
\text { indicators }\end{array}$ & Positive & Supported \\
\hline H3 & SC & $\begin{array}{l}\text { CFP measured by } \\
\text { accounting-based } \\
\text { indicators and } \\
\text { stock market value }\end{array}$ & $\begin{array}{l}\text { Positive; } \\
\text { The positive association is stronger } \\
\text { between OC and CFP than between TC } \\
\text { and CFP }\end{array}$ & Supported \\
\hline $\mathrm{H} 4$ & $\mathrm{RC}$ & $\begin{array}{l}\text { CFP measured by } \\
\text { customer metrics } \\
\text { and stock market } \\
\text { value }\end{array}$ & $\begin{array}{l}\text { Positive; } \\
\text { The relationship between CBBE and } \\
C F P \text { is negative whereas the link } \\
\text { between customer relationship capital } \\
\text { and CFP is positive }\end{array}$ & Supported \\
\hline
\end{tabular}

Table 4 - Summary of the findings

Ultimately, we can legitimately question why certain IC components found in the theoretical frame of IC (see Figure 2) are either partially measured or not measured at all by empirical studies. There are two possible explanations: either these components are not contributing to IC or they are too difficult to measure. Empirical research on $\mathrm{HC}$ only covers knowledge and abilities, disregarding employee behaviour. What can be argued here is that employee behaviour may not be an asset as such, but rather a result of the mobilization of two other components of $\mathrm{HC}$ : knowledge and abilities. Notably, managerial actions such as training programmes can be envisaged to increase knowledge and abilities, whereas it is much less feasible to directly influence employee behaviour. Similarly, organizational culture and relationships to society are not measured by empirical studies, probably because these concepts are contingent, multi-dimensional and therefore difficult to measure.

\section{DISCUSSION AND RESEARCH AGENDA}

The theoretical discussion is organized around four themes: (1) how this work contributes to RBT in broad terms and a redefinition of IC; (2) the possibility of reverse associations between IC and CFP; (3) the effect of measurement tools on how IC is perceived; and (4) questioning the actual accounting framework. 


\section{CONTRIBUTION TO RESOURCE-BASED THEORY AND A REDEFINITION OF IC}

RBT focuses on the identification of specific resources and their contribution to performance. Nonetheless, our results highlight that some IC components are interrelated in their association with financial performance. The association between $\mathrm{OC}$ and financial performance overlaps with that between $\mathrm{HC}$ and financial performance, leading us to conclude that these two IC components are deeply interrelated. Indeed, the knowledge and abilities of employees contribute to the performance of the firm when they are used together through processes and procedures structuring the firm, leading to value creation. Moreover, some specific IC components, such as brand, could be considered as the final result of a combination of tangible assets (flagship stores, Zara's state-of-the art supply chain) and intangible assets, such as design (Apple, Swatch) or know-how (Hermès and other luxury brands). Empirical studies underestimate the value created by the combination of assets, because they are studied in isolation. These considerations echo recent developments in RBT. Indeed, a limitation of RBT is that it focuses on longlasting differences between competitors and on its financial consequences, therefore neglecting the antecedents of the performance. Hence, two streams of research have recently challenged the traditional vision of RBT that largely ignores managerial actions. The first stream, resource orchestration (Helfat, 2007; Sirmon, Hitt, Ireland \& Gilbert, 2011), argues that performance comes from the managerial choices and abilities to jointly use the resources rather than from the resource in itself (Chadwick, 2017; Lechner \& Gudmundsson, 2012). In the same vein, Molloy and Barney (2015) present the notion of co-specialized assets to explain the added value given by the combination of $\mathrm{HC}$ with a non-human resource (physical, technical or financial), implying that $\mathrm{HC}$ cannot be disentangled from other forms of capital. This is indeed empirically confirmed by our results as $\mathrm{HC}$ and $\mathrm{OC}$ relationships with CFP overlap, which suggests that these IC components are combined.

This overlap can be explained twofold. Either $\mathrm{HC}$ matters more than $\mathrm{OC}$, as for instance in professional service firms characterized by knowledge intensity, low capital intensity and skilled workforce. In that case, sloppy management and weak processes do not necessarily undermine performance which relies heavily on people's 'skills and abilities (Von Nordenflycht, 2010). Or, on the contrary, OC can prevail over HC, as for instance in firms operating in services on a large scale, such as ground crews in airline companies or receptionists in hotel chains. Von Nordenflycht (2010) cites McDonalds as an example because each outlet is run by the same routines and procedures. Chanda, Ray \& McKelvey (2018) show that not all companies necessarily need to develop HC to be financially successful since this depends on the company's strategic orientation towards exploration or exploitation. For instance, a company operating in the bottom-of-the-pyramid segment can be financially successful with a low level of $\mathrm{HC}$.

Similarly, other scholars have criticized the RBT, arguing that it focuses too much on the innate features of resources hindering the way they are brought into use (Feldman \& Worline, 2012). The proponents of the so-called resourcing theory go as far as to say that resources as such do not matter; what is important is the action taken to use the resources. This is partly reflected in the nature of the proxies selected in the sample of studies. Indeed, a distinction can be made between proxies corresponding to a resource (e.g. R\&D expenditure) and proxies related to the use of a 
resource (e.g. innovation capabilities). Even if the majority of the proxies used in our sample studies directly refer to resources as such, in accordance with the classical view of RBT (see Appendix A), some address the complex issue of resources in-use, usually under the umbrella terms of "capabilities" or "implementation". Further development of RBT could include other type of indicators measuring the effective use of resources rather than the resources themselves.

Finally, although many attempts have already been made to define IC-from the strict interpretation of accounting research to definitions in strategy that consider capabilities and competencies-none have reached a consensus so far (Dean \& Kretschmer, 2007). From our results, and with the aim of reconciling those different views with a management perspective, we propose to define IC as follows: Intellectual capital is at once the stock of cognitive knowledge and relational skills collectively built in an organization, and the effective use made of it.

\section{A CHICKEN AND EGG DILEMMA}

Another concern emerges from the results regarding the cause-toeffect chain. In the RBT literature, it is conventionally assumed that IC gives a firm competitive advantage, which in turn supports financial performance. We might expect that when a firm enjoys additional resources from stronger financial performance, it can invest in employees' well-being, which will in turn foster positive employee behaviour and organizational culture. For example, Google has heavily leveraged IC components such as TC, knowledge and abilities, which has provided competitive advantage and outstanding financial performance that have enabled the company to invest in employees' well-being, to the extent that in 2017 it came first in the list of Fortune's Best Companies to Work For, for the sixth year running. Another case is reported by Lechner and Gudmundsson (2012) for football clubs, where high financial performance allows significant investments in renowned athletes. The relationship between IC and CFP could thus be viewed as a virtuous cycle in which some components of IC positively influence CFP, which then allows firms to invest in other assets that are crucial for the value creation process. Yet, the literature is inconclusive about this relation. If, for some authors, an excess of financial resources can lead to the development of IC components (Lechner \& Gudmundsson, 2012; Nohria \& Gulati, 1996), for others an abundance of resources can conversely foster inertia and inhibit change through the phenomenon of "competency trap" (Leonard, 1992; Levinthal \& March, 1993).

\section{A distorting prism of measurement tools of IC}

The meta-analysis shows that the overall association between $\mathrm{RC}$ and CFP is negative. When examining the results further, we find that this analysis masks notable differences between the positive impact on customer metrics and stock market value and the negative influence on accounting-based measures such as ROA, ROE, ROI or net profit. This examination highlights the fact that accounting systems are not ideal for measuring the RC value when generated internally by the company (Wyatt, 2008). In certain ways, both investors and customers (firm outsiders) perceive value that is not registered by the accountant (firm insiders). Among RC components, it appears that the situation is exacerbated for native brands (for instance, there is an important gap between Apple's accounting value and market value). One possible explanation lies in the 
distorting prism of the measurement tools. As stated by Martineau (2017), the accounting framework can be considered as an example of a "closed list", implying an equality between all IC components. This formal representation does not fully translate either the crossed effects or the overall picture.

\section{When IC questions the accounting framework}

Top management regularly refers to branding efforts as expenses because they represent a significant amount of money, diminishing the annual profit, whereas in fact they generate a return after a longer period of time. Indeed, branding efforts are always reported as expenses rather than investments in the IFRS accounting framework and can be registered as assets only under restrictive conditions in the US GAAP accounting framework.

As a result, considering investments in $\mathrm{IC}$ as expenses in profit and losses damages future earnings by hampering value creation. A partial integration of these expenses into the balance sheet could provide organizations with new knowledge and additional flexibility. Making these IC components visible in the company's balance sheet would encourage top management to consider IC manageable. Thus, the resource allocation between the different IC components should be more precise in relation to their future earnings. Furthermore, managers would be incentivized to manage IC components properly because the consequences of failure in IC management would be visible. This challenge is significant for both managers and scholars, who must determine the amount of future earnings provided by investment in IC such as brands. This challenge could be addressed, however, because the results of this meta-analysis have proven a positive association between RC and customer metrics such as preference rate or propensity to pay a premium price.

\section{Towards a research agenda}

The results of this research open new avenues for research in four directions: (1) identification and classification of IC components; (2) understanding of the combination and orchestration of IC; (3) improvement of indicators and measurement systems of IC; and (4) enhancement of the understanding of value creation through narrative means.

The first direction involves clarification of the definition of IC components according to their nature. Some components, such as $\mathrm{OC}, \mathrm{HC}$ or customer relationship, are profoundly embedded in the organization's structure, history and culture. Indeed, by their very nature, they cannot really be disentangled from the organization itself. Interestingly, these are also the IC components that have a better overall association with CFP. However, their qualification as assets may be questioned, as (1) they cannot be sold apart and (2) the organization does not really "own" them, especially in the case of HC (Chadwick, 2017). In contrast, other IC components, such as brands or technologies, are more readily separable from the organization. They can be set apart, monetized or even sold. These components are penalized by a weaker association with CFP (even a negative association in the case of brands). However, they can eventually provide high returns, and investors may therefore value them to a greater extent than accounting performance. More research is needed to examine the identification of IC components and provide a better classification according to their nature. Classification can be refined by the 
addition of other criteria, such as tradability, ownership and time span, as shown in Figure 3.

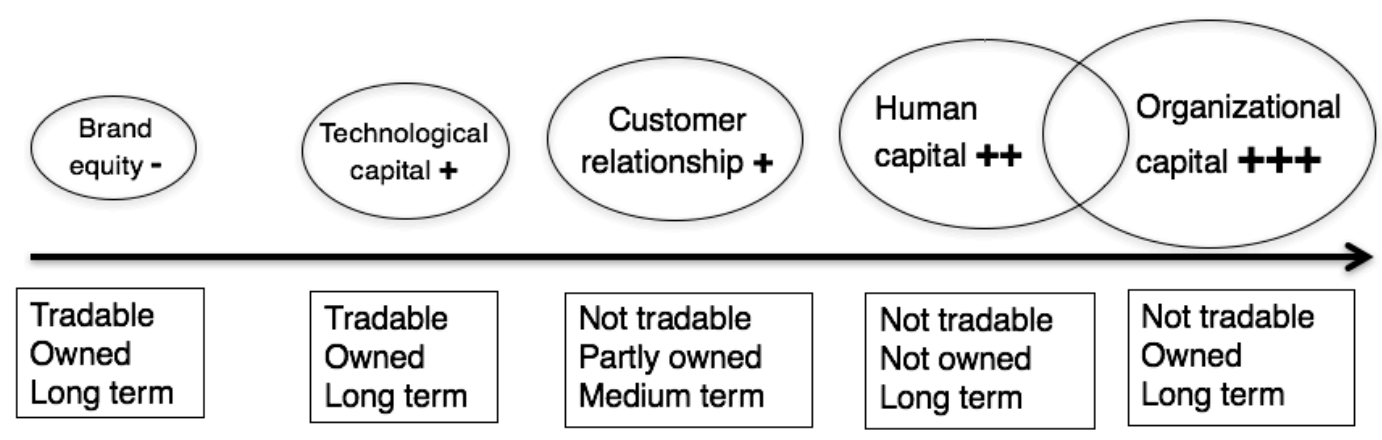

$+/$ - illustrates the strength of the association with CFP

Figure 3. Proposal for a conceptual framework of intellectual capital

A second area of research that might prove fruitful is the combination of IC components. It is unlikely that IC components create value in isolation, and it is much more likely that they do so in combination with others. We might go so far as to say that some IC components provide value only if combined with others. For instance, the very specific knowhow about saddle stitch among female Hermès workers creates value because it is combined with Hermès' brand equity. This fits well with the notion of resource portfolio (Barney et al., 2011) and resource orchestration (Sirmon et al., 2011). An association can also occur between tangible and intangible assets, for instance, a flagship store associated with a brand. Research questions that require further investigation include: Are there IC components that work only in combination? Can we identify patterns of combination, i.e. IC components that provide higher value when combined? How can we evaluate the value of the combination itself? Is there a way of comparing the results of varied combinations?

Third, the results of this research pave the way towards a better understanding of the efficiency of managerial actions. As the overall association between IC and CFP is positive, this requires both a follow-up and a set of key performance indicators (KPIs) so that managers can move the strategic levers of value creation. Yet, accounting-based indicators are only partial measures and customer metrics and other managerial KPIs may be flawed, or at least too specific and contextual to be comparable between organizations. At best, some components can be identified and measured, but the knowledge and measurement of the interactions between them remain scarce. Future research should focus on metrics that could better reflect the full complexity of value creation to complement accounting-based indicators. These metrics could provide a better representation of the value creation of intangibles and a better account of the interaction effects between various IC components and tangibles and intangibles.

Finally, companies also disclose information about their value creation process through narrative means in addition to indicators and measurement systems. They do so to reduce the discrepancies between companies operating through external expansion (IC components recorded 
in financial statements), and those favouring internal growth (no IC record in financial statements). This is also a way to disclose information to investors on native brands and other intangibles that potentially penalize CFP. Indeed, value creation through intangibles cannot be fully captured by numbers. This is not to imply that investors, or managers, get no information at all about this value creation. They get it through narrative means, such as corporate communication, opinion leaders' "voice", managers' "voice" or internal communications. Research directed towards this could take either a comprehensive or a normative view. A comprehensive view would result in an in-depth understanding of narrative means used by organizations, both inside and outside the firm, to provide information and direction on value creation through intangibles. From a more normative perspective, it could be interesting to reflect upon the feasibility of an "inventory", or an annual report, of intangibles. If it seems difficult to set norms when it comes to narrative means, management scholars could at least provide guidelines for producing such a document. It seems urgent, and necessary, to set information standards that would overcome the incompleteness of accounting-based ratios. This is at the same time a transparency requirement, an expectation among investors and a way of containing speculative bubbles. This has been partly covered by the integrated reporting framework provided by the International Integrated Reporting Council (IIRC, 2011, 2013), which aims to "enhance accountability and stewardship for the broad base of capitals (financial, manufactured, intellectual, human, social and relationship, and natural) and promote understanding of their interdependencies" (IIRC, 2013: 2). Even though its intention is commendable, the scope and recommendations of the IIRC remain too broad, not directly actionable by managers and too discretionary regarding the requirements for disclosure and implementation (Robertson \& Samy, 2015; Simnett \& Huggins, 2015). This creates space for an array of contributions regarding quantitative KPIs and mandatory qualitative information that could usefully complement disclosure on value creation such as customer commitment, potential brand extensions or quality of internal processes.

\section{Managerial contributions}

A superficial analysis of our results might lead to the conclusion that, from a managerial perspective, it is somehow better not to invest in IC such as brands, to avoid uncertainty related to high costs and risk on investment return. This shortcut, often taken by decision makers, explains why decisions about IC, such as brands, are difficult to make at the board level and why they are often made based on "gut feelings". Indeed, there is a discrepancy between the nature of the value created and the monitoring systems. Management control systems cannot monitor IC properly because they have been constructed to manage fixed assets and they rely on average performance, therefore underestimating weak signals (Andriani \& McKelvey, 2011). Managers, then, are forced to "see through the fog" and take risks if they want to invest in IC. This explanation underscores why success stories in building IC are reported as a result of bold, unconventional managers who disregard rules and procedures. We might wonder whether large corporation are "equipped" to create value today; this might help explain why the Accor group did not create Airbnb or why Steve Jobs did not run Apple in a traditional way.

Nevertheless, the results of this meta-analysis confirm that managers may be more likely to pursue IC management to create value because IC positively influences CFP. To convince their boards, managers 
should mobilize customer metrics, such as the propensity to pay a premium price, while calculating a ROI over a longer period of time and measuring the impact on investors' perceptions. A full review of management control systems may then be needed to properly guide managers' actions and decisions.

Moreover, IC management questions the traditional functional organization of the firm. Proper IC management would require transversal management and thus decompartmentalization of the company. With regards to IC, it seems necessary to shift towards better management of complexity (Morin, 2008; Ramus, Vaccaro \& Brusoni, 2017).

\section{Limitations and conclusions}

Overall, our results indicate that the association between IC and CFP is positive, with similar results being obtained for HC and CFP, and $\mathrm{SC}$ and CFP. However, the association between RC and CFP is negative, leading us to delve more deeply into the nature of RC. Indeed, this negative association is linked to CBBE, which negatively affects the net profit of the company, whereas the association remains positive when measured using stock market value and customer metrics.

The results of this study must be interpreted with caution. IC and its components and CFP are meta-constructs that can be operationalized in a variety of ways. The "estimate" calculated in this meta-analysis depends on the researchers' choices of IC and CFP measures and on their theoretical significance. Furthermore, this effect size is calculated from different studies, countries, periods and operational definitions used in measuring the explanatory variables and from a variety of research methods. Another limitation of our meta-analysis lies in the difficulty of accounting for endogeneity caused by reverse causality or omitted variables in the primary studies. Reverse causality refers to a probable two-way causal link between financial performance and IC components, as already pointed out in the discussion section. Indeed, although the vast majority of studies used in this meta-analysis account for a relationship going from IC to financial performance, it is very likely that the relationship also works the other way round in a feedback loop. As a matter of fact, financial performance enables investments in highly skilled employees, R\&D projects and/or branding activities.

Endogeneity is potentially also caused by omitted variables in primary studies. In fact, variables such as the competitive intensity or the business sector may affect the relationship between IC and financial performance. For instance, the relationship between $\mathrm{HC}$ and financial performance is arguably stronger in business sectors requiring highly skilled employees such as in knowledge-intensive firm than in business sectors requiring large and interchangeable workforce (Von Nordenflycht, 2010). Of the studies in our sample, very few addressed possible endogeneity. However, our results should be interpreted with caution as the quality of a meta-analysis depends on the quality of prior results. Hence, we call for research that attempts to (1) elucidate potential reverse causality, that is, high financial performance leads to an increase of IC components, and (2) include more variables to enhance the explanatory power of the models. For the latter, the relationship between IC and financial performance could potentially be influenced by other variables such as intellectual property regulation levels, competitive intensity, accounting standards, type of governance (shareholders, family business), listed versus non-listed companies, level of equity, ease of access to financial resources or conversely scarcity of resources (for instance, 
scarce supply of qualified workforce in specific sectors). This calls for a much thinner identification of the sample characteristics in published papers, notably by including a great deal of more qualitative variables.

Finally, the statistical significance of our results does not necessarily imply economic significance (Ziliak \& McCloskey, 2008). Indeed, scholars should not be interested only in whether there is an effect (tested by statistical significance) but in how big this effect is (tested by economic significance). However, establishing an order of magnitude in management studies poses significant challenges, as it is difficult to obtain good reliable parameter estimates (Engsted, 2009). This is probably why economic significance is barely discussed in meta-analysis in the strategy or management fields (Doucouliagos \& Laroche, 2003). Still, it could be interesting in further studies to compare the magnitude of estimated coefficients within firm size, business sectors or geography in order to grasp the economic significance of the results.

Despite these limitations and concerns, meta-analysis is a wellestablished social science technique for aggregating test statistics, and the inclusion criteria used in this paper are consistent with the literature.

Moreover, since meta-analysis supports a holistic view of a subject that is often seen as scattered, our results lead us to propose an extensive research agenda for IC. Notably, the nature of certain components of IC capital, including brands, organizational culture, employee behaviour and corporate reputation, makes them difficult to measure and therefore to manage. Part of the solution involves the recognition that these IC components are eminently volatile and embedded in the company, and therefore cannot be accurately measured using classical indicators. This challenge calls for more innovative ways of appreciating the value of such intangible assets including narrative means. 


\section{APPENDIX - LIST OF PROXIES USED BY THE STUDIES INCLUDED IN THIS META-ANALYSIS}

\begin{tabular}{|c|c|c|}
\hline IC component & Sub-component & Proxy \\
\hline Human capital & None & $\begin{array}{l}\text { Average educational level of employees, training } \\
\text { methods, total expenditures on training, human } \\
\text { capabilities, human resource assets }\end{array}$ \\
\hline \multirow[t]{2}{*}{ Structural capital } & Technological & $\begin{array}{l}\text { R\&D expenditures, R\&D expenditures/sales, } \\
\text { innovation capabilities, number of patents granted, } \\
\text { broad technology diversity, implementation of } \\
\text { technologies }\end{array}$ \\
\hline & Organizational & $\begin{array}{l}\text { Ratio of IT expenses to total administrative expenses, } \\
\text { ratio of administrative expenses to total revenue, } \\
\text { implementation of information systems }\end{array}$ \\
\hline \multirow{2}{*}{ Relational capital } & Customer relationship & $\begin{array}{l}\text { Key account ratio, commercial capabilities, customer } \\
\text { acquisition, customer retention, customer service } \\
\text { quality, responsiveness to customers, customer } \\
\text { satisfaction, customer equity, customer loyalty }\end{array}$ \\
\hline & $\begin{array}{l}\text { Customer-Based } \\
\text { Brand Equity (CBBE) }\end{array}$ & $\begin{array}{l}\text { Advertising expenses, ratio of advertising expenses to } \\
\text { sales, advertising to sales, brand attitude, satisfaction } \\
\text { and involvement, brand name, brand value, number } \\
\text { of brands }\end{array}$ \\
\hline \multirow{3}{*}{$\begin{array}{l}\text { Financial } \\
\text { performance }\end{array}$} & $\begin{array}{l}\text { Accounting-based } \\
\text { indicators }\end{array}$ & $\begin{array}{l}\text { ROA, ROE, ROI, profit, benefit before interest and } \\
\text { taxes }\end{array}$ \\
\hline & Customer metrics & Price premium, sales, market share \\
\hline & Stock market value & $\begin{array}{l}\text { Abnormal stock return, market to book, holding stock } \\
\text { period return, Tobin's } q \text {, share value, market value }\end{array}$ \\
\hline
\end{tabular}




\section{REFERENCES}

Amir, E., Lev, B. \& Sougiannis, T. (2003). Do Financial Analysts Get Intangibles? European Accounting Review, 12(4), 635-659.

Anderson, E.W., Fornell, C. \& Lehmann, D.R. (1994). Customer Satisfaction, Market Share, and Profitability: Findings From Sweden. Journal of Marketing, 58(3), 53-66.

Andriani, P. \& McKelvey, B. (2011). Managing in a Pareto World Calls for New Thinking. M@n@gement, 14(2), 90-118.

Angulo-Ruiz, F., Donthu, N., Prior, D. \& Rialp, J. (2014). The Financial Contribution of Customer-oriented Marketing Capability. Journal of the Academy of Marketing Science, 42(4), 380-399.

Aragon-Sanchez, A., Barba-Aragon, I. \& Sanze-Valle, R. (2003). Effects of Training on Business Results. International Journal of Human Resource Management, 14(6), 956-980.

Artz, K.W., Norman, P.M., Hatfield, D.E. \& Cardinal, L.B. (2010). A Longitudinal Study of the Impact of R\&D, Patents, and Product Innovation on Firm Performance. Journal of Product Innovation Management, 27(5), 725-740.

Barney, J.B. (1991). Firm Resources and Sustained Competitive Advantage. Journal of Management, 17(1), 99-120.

Barney, J.B. (1999). How a Firm's Capabilities Affect Boundary Decisions. Sloan Management Review, 40(3), 137-145.

Barney, J.B., Ketchen, D.J. \& Wright, M. (2011). The Future of Resource-based Theory: Revitalization or Decline? Journal of Management, 37(5), 1299-1315.

Barney, J.B., Wright, M. \& Ketchen, D. (2001). The Resource-based View of the Firm: Ten Years after 1991. Journal of Management, 27(6), 625-641.

Barth, M.E. (2015). Financial Accounting Research, Practices, and Financial Accountability. Abacus, 51(4), 499-510.

Barth, M.E., Clement, M.B., Foster, G. \& Kasznick, R. (1998). Brand Values and Capital Market Valuation. Review of Accounting Studies, 3(1-2), 41-68.

Berthon, P., Holbrook, M.B., Hulbert, J M. \& Pitt, L. (2007). Viewing Brands in Multiple Dimensions. MIT Sloan Management Review, 48(2), 37.

Bharadwaj, A.S., Bharadwaj, S G. \& Konsynski, B.R. (1999). Information Technology Effects on Firm Performance As Measured by Tobin's q. Management Science, 45(7), 1008-1024.

Bijmolt, T H.A. \& Pieters, R.G.M. (2001). Meta-Analysis in Marketing when Studies Contain Multiple Measurements. Marketing Letters, 12(2), 157-169.

Bollen, L., Vergauwen, P. \& Schnieders, S. (2005). Linking Intellectual Capital and Intellectual Property to Company Performance. Management Decision, 43(9), 1161-1185.

Bontis, N. (1998). Intellectual Capital: An Exploratory Study that Develops Measures and Models. Management Decision, 36(2), 63-76.
Bontis, N., Crossan, M M. \& Hulland, J. (2002). Managing an Organizational Learning System by Aligning Stocks and Flows. Journal of Management Studies, 39(4), 437-469.

Bontis, N. \& Fitz-Enz, J. (2002). Intellectual Capital ROI: A Causal Map of Human Capital Antecedents and Consequents. Journal of Intellectual Capital, 3(3), 223-247.

Borenstein, M. (1997), Comprehensive Meta-Analysis, Englewood Cliffs, $\mathrm{NJ}$ : Biostat.

Certo, S.T., Lester, R.H., Dalton, C.M. \& Dalton, D.R. (2006). Top Management Teams, Strategy and Financial Performance: A Meta-Analytic Examination. Journal of Management Studies, 43(4), 813-839.

Chadwick, C. (2017). Toward a More Comprehensive Model of Firms' Human Capital Rents. Academy of Management Review, 42(3), 499-519.

Chanda, S.S., Ray, S. \& McKelvey, B. (2018). The Continuum Conception of Exploration and Exploitation: An Update to March's Theory. M@n@gement, 21(3), 1050-1079.

Changeur, S. (2004). Stratégie de marque et richesses des actionnaires: une approche financière du capital-marque. Recherche et Applications en Marketing, 19(4), 23-38.

Cheung, S.F. \& Chan, D.K.S. (2004). Dependent Effect Size in Meta-Analysis: Incorporating the Degree of Interpendence. Journal of Applied Psychology, 85(5), 780-791.

Cho, H.J. \& Pucik, V. (2005). Relationship Between Innovativenes, Quality, Growth, Profitability, and Market Value. Strategic Management Journal, 26(6), 555-575.

Cohen, J A. (2011), Intangible Assets: Valuation and Economic Benefits, (Vol. 273), New York, NY: John Wiley \& Sons.

Conchar, M.P., Crask, M.R. \& Zinkhan, G.M. (2005). Market Valuation Models of the Effect of Advertising and Promotional Spending: A Review and MetaAnalysis. Journal of the Academy of Marketing Science, 33(4), 445-460.

Coombs, J.E. \& Bierly, P E. (2006). Measuring Technological Capability and Performance. $R \& D$ Management, 36(4), 421-438.

Coviello, N., Winklhofer, H. \& Hamilton, K. (2006). Marketing Practices and Performance of Small Service Firms. Journal of Service Research, 9(1), 38-58.

Crook, T.R., Ketchen, D.J., Combs, J.G. \& Todd, S.Y. (2008). Strategic Resources and Performance: A Meta-analysis. Strategic Management Journal, 29(11), 1141-1154.

Dalton, D.R., Daily, C.M., Certo, S.T. \& Roengpitya, R. (2003). Meta-analyses of Financial Performance and Equity: Fusion or Confusion? Academy of Management Journal, 46(1), 13-26.

Damanpour, F. (1991). Organizational Innovation: A Meta-analysis of Effects of Determinants and Moderators. Academy of Management Journal, 34(3), 555-590. 
Davies, G., Chun, R. \& Kamins, M.-A. (2010). Reputation Gaps and the Performance of Service Organizations. Strategic Management Journal, 31(5), 530-546.

de Chernatony, L., Riley, F.D.O. \& Harris, F. (1998). Criteria to Assess Brand Success. Journal of Marketing Management, 14(7), 765-781.

Dean, A. \& Kretschmer, M. (2007). Can Ideas be Capital? Factors of Production in the Postindustrial Economy: A Review and Critique. Academy of Management Review, 32(2), 573-594.

Diamond, N., Sherry Jr, J.F., Muñiz Jr, A.M., McGrath, M.A., Kozinets, R.V. \& Borghini, S. (2009). American Girl and the Brand Gestalt: Closing the Loop on Sociocultural Branding Research. Journal of Marketing, 73(3), 118-134.

do Rosario-Cabrita, M. \& Bontis, N. (2008). Intellectual Capital and Business Performance in the Portuguese Banking Industry. International Journal of Technology Management, 43(1-3), 212-237.

Doucouliagos, H. \& Laroche, P. (2003). What Do Unions Do to Productivity? A Meta-analysis. Industrial Relations, 42(4), 650-691.

Edeling, A. \& Fischer, M. (2016). Marketing's Impact on Firm Value: Generalizations from a Meta-analysis. Journal of Marketing Research, 53(4), 515-534.

Edvinsson, L. \& Malone, M. (1997), Intellectual Capital Realizing Your Company's True Value by Finding Its Hidden Brainpower, New York, NY: Harper Collins Publishers, Inc.

Eggers, F., Kraus, S., Hughes, M., Laraway, S. \& Snycerski, S. (2013). Implications of Customer and Entrepreneurial Orientations for SME Growth. Management Decision, 51(3), 524-546.

Eisend, M. (2009). A Meta-analysis of Humour in Advertising. Journal of the Academy of Marketing Science, 37(2), 191-203.

Engsted, T. (2009). Statistical vs. Economic Significance in Economics and Econometrics: Further Comments on McCloskey and Ziliak. Journal of Economic Methodology, 16(4), 393-408.

Erdem, T. \& Swait, J. (1998). Brand Equity As a Signaling Phenomenon. Journal of Consumer Psychology, 7(2), 131-157.

Ettlie, J.E. (1998). R\&D and Global Manufacturing Performance. Management Science, 44(1), 1-11.

Farquhar, P H. (1989). Managing Brand Equity. Marketing Research, 1(Sept), 24-33.

Feldman, M. \& Worline, M. (2012). Resources, Resourcing, and Ampliative Cycles in Organizations. In K. Cameron \& G. Spreitzer (Eds.), The Oxford Handbook of Positive Organizational Scholarship (pp. 629-641). New York, NY: Oxford University Press.

Fournier, S. (1998). Consumers and Their Brands: Developing Relationship Theory in Consumer Research. Journal of Consumer Research, 24(4), 343-373.

Gowthorpe, C. (2009). Wider Still and Wider? A Critical Discussion of Intellectual Capital Recognition, Measurement and Control in a Boundary Theoretical Context. Critical Perspectives on Accounting, 20(7), 823-834.
Grinstein, A. (2008). The Effect of Market Orientation and its Components on Innovation Consequences: A Meta-analysis. Journal of the Academy of Marketing Science, 36(2), 166-173.

Guérard, S., Langley, A. \& Seidl, D. (2013). Rethinking the Concept of Performance in Strategy Research: Towards a Performativity Perspective. M@n@gement, 16(5), 566-578.

Gupta, S. \& Zeithaml, V. (2006). Customer Metrics and their Impact on Financial Performance. Marketing Science, 25(6), 718-739.

Hedges, L.V. \& Olkin, I. (1985), Statistical Methods for Meta-Analysis, Orlando, FL: Academic Press.

Heiens, R.A., Leach, R.T. \& McGrath, L.C. (2007). The Contribution of Intangible Assets and Expenditures to Shareholder Value. Journal of Strategic Marketing, 15(2-3), 149-159.

Helfat, C.E. (2007), Dynamic Capabilities: Understanding Strategic Change in Organizations, New York, NY: Wiley-Blackwell.

Higgins, J.P.T. \& Thompson, S.G. (2002). Quantifying Heterogeneity in a Meta-analysis Statistics. Statistics in Medecine, 2(11), 1539-1558.

Holbrook, M.B. (1992). Product Quality, Attributes, and Brand Name as Determinants of Price: The Case of Consumer Electronics. Marketing Letters, 3(1), 71-83.

Hooley, G.J., Greenley, G.E., Cadogan, J.W. \& Fahy, J. (2005). The Performance Impact of Marketing Resources. Journal of Business Research, 58(1), 18-27.

Hsu, L.C. \& Wang, C.-H. (2012). Clarifying the Effect of Intellectual Capital on Performance: The Mediating Role of Dynamic Capability. British Journal of Management, 23(2), 179-205.

Hsu, Y., Fang, H. \& Fang, W. (2009). Intellectual Capital and New Product Developement Performance: The Mediating Role of Organizational Learning Capabilitiy. Technological Forecasting and Social Change, 76(5), 664-677.

Huedo-Medina, T.B., Sanchez-Meca, J., MarinMartinez, F. \& Botella, J. (2006). Assessing Heterogeneity in Meta-analysis: $Q$ Statistic of $F$ Index? Psychological Methods, 11(2), 193-206.

Hunter, J.E. \& Schmidt, F.L. (1990), Methods of Metaanalysis: Correcting Error and Bias in Research Findings, (1st ed.), Thousand Oaks, CA: Sage Publications.

Hunter, J.E. \& Schmidt, F.L. (2004), Methods of Metaanalysis: Correcting Error and Bias in Research Findings, (2nd ed.), Thousand Oaks, CA: Sage Publications.

Hunter, J E., Schmidt, F.L. \& Jackson, G B. (1982), Meta-analysis: Cumulating Research Findings Across Studies, Thousand Oaks, CA: Sage Publications.

IIRC (International Integrated Reporting Council) (2011). Towards Integrated Reporting Communication Value in the 21st Century. Available at www.theiirc/international-ir-framework.

IIRC (International Integrated Reporting Council) (2013). The International <IR> Framework. Available at www.theiirc.org/international-irframework. 
Johnson, M.D. \& Selnes, F. (2004). Customer Portfolio Management: Toward a Dynamic Theory of Exchange Relationships. Journal of Marketing, 68(2), 1-17.

Juma, N. \& Payne, G.T. (2004). Intellectual Capital and Performance of New Venture High-tech Firms. International Journal of Innovation Management, 8(3), 297-318.

Keller, K.L. (1993). Conceptualizing, Measuring, Managing Customer-based Brand Equity. Journal of Marketing, 57(1), 1-22.

Kimbrough, M.D., McAlister, L., Mizik, N., Jacobson, R., Garnaise, M.J., Srinivasan, N. \& Hanssens, D M. (2009). Commentaries and Rejoinder to "Marketing and Firm Value: Metrics, Methods, and Future Directions". Journal of Marketing Research, 46(3), 313-329.

King, D.R., Dalton, D.R., Daily, C.M. \& Covin, J.G. (2004). Meta-analyses of Post-acquisition Performance: Indications of Unidentified Moderators. Strategic Management Journal, 25(2), 187-200.

Kirk, C.P., Ray, I. \& Wilson, B.K. (2013). The Impact of Brand Value on Firm Valuation: The Moderating Influence of Firm Type. Journal of Brand Management, 20(6), 488-500.

Kohli, A K. \& Jaworski, B.J. (1990). Market Orientation: The Construct, Research Propositions and Managerial Implications. The Journal of Marketing, 54(2), 1-18.

Kostova, T. \& Roth, K. (2003). Social Capital in Multinational Corporations and a Micro-Macro Model of Its Formation. Academy of Management Review, 28(2), 297-317.

Lechner, C. \& Gudmundsson, S.V. (2012). Superior Value Creation in Sports Teams: Resources and Managerial Experience. M@n@gement, 15(3), 284-312.

Leonard, D.A. (1992). Core Capability and Core Rigidities: A Paradox in Managing New Product Development. Strategic Management Journal, 13(1), 111-125.

Lev, B. \& Zambon, S. (2003). Intangibles and Intellectual Capital: An Introduction to a Special Issue. European Accounting Review, 12(4), 597-603.

Levinthal, D.A. \& March, J.G. (1993). The Myopia of Learning. Strategic Management Journal, 14(2), 95-112.

Lin, B.W., Chen, C J. \& Wu, H.L. (2006). Patent Portfolio Diversity, Technology Strategy, and Firm Value. Engineering Management, IEEE Transactions, 53(1), 17-26.

Lin, B.W., Lee, Y. \& Hung, S.C. (2006). R\&D Intensity and Commercialization Orientation Effects on Financial Performance. Journal of Business Research, 59(6), 679-685.

Ling, Y.-H. \& Jaw, B.-S. (2006). The Influence of International Human Capital on Global Initiatives and Financial Performance. International Journal of Human Resource Management, 17(3), 379-398.

Lipsey, M.W. \& Wilson, D.B. (2001), Applied Social Research Methods Series, Vol.49, Pratical Metaanalysis. Thousand Oaks, CA: Sage.
Livne, G., Simpson, A. \& Talmor, E. (2011). Do Customer Acquisition Cost, Retention and Usage Matter to Firm Performance and Valuation? Journal of Business Finance \& Accounting, 38(3-4), 334-363.

Luo, X., Griffith, D.A., Liu, S.S. \& Shi, Y.-Z. (2004). The Effects of Customer Relationships and Social Capital on Firm Performance: A Chinese Business Illustration. Journal of International Marketing, 12(4), 25-45.

Madden, T J., Fehle, F. \& Fournier, S. (2006). Brands Matter: An Empirical Demonstration of the Creation of Shareholder Value Trough Branding. Journal of the Academy of Marketing Science, 34(2), 224-235.

Marr, B. \& Moustaghfir, K. (2005). Defining Intellectual Capital: A Three-dimensional Approach. Management Decision, 43(9), 114-1128.

Martin-de-Castro, G., Delgado-Verde, M., Lopez-Saez, P. \& Navas-Lopez, J. (2011). Towards an "Intellectual Capital-based View of the Firm"; Origins and Nature. Journal of Business Ethics, 98(4), 649-662.

Martineau, R. (2017). What Are Management Tools Made of? The "Listic" Structure of Managerial Artifacts. M@n@gement, 20(3), 239-262.

Matsuno, K., Zhu, Z. \& Rice, M.P. (2014). Innovation Process and Outcomes for Large Japanese Firms: Roles of Entrepreneurial Proclivity and Customer Equity. Journal of Product Innovation Management, 31(5), 1106-1124.

Matzler, K., Hinterhuber, H.H., Daxer, C. \& Huber, M. (2005). The Relationship Between Customer Satisfaction and Shareholder Value. Total Quality Management \& Business Excellence, 16(5), 671-680.

McAlister, L., Srinivasan, R. \& Kim, M. (2007). Advertising, Research and Development, and Systematic Risk of the Firm. Journal of Marketing, 71(1), 35-48.

McEnally, M.R. \& De Chernatony, L. (1999). The Evolving Nature of Branding: Consumer and Managerial Considerations. Academy of Marketing Science Review, 2(1), 1-16.

Mizik, N. \& Jacobson, R. (2008). The Financial Value Impact of Perceptual Brand Attributes. Journal of Marketing Research, 45(1), 15-32.

Mizik, N. \& Jacobson, R. (2009). Valuing Branded Businesses. Journal of Marketing, 73(6), 137-153.

Molloy, J.C. \& Barney, J.B. (2015). Who Captures the Value Created with Human Capital? a Market-based View. The Academy of Management Perspectives, 29(3), 309-325.

Molloy, J.C., Chadwick, C., Ployhart, R.E. \& Golden, S.J. (2011). Making Intangibles "Tangibles" in Test of Resource-based Theory: A Multidisciplinary Construct Validation Approach. Journal of Management, 37(5), 1496-1518.

Morgan, N.A. (2012). Marketing and Business Performance. Journal of the Academy of Marketing Science, 40(1), 102-119.

Morgan, N.A. \& Rego, L.L. (2009). Brand Portfolio Strategy and Firm Performance. Journal of Marketing, 73(1), 59-74.

Morin, E. (2008), On Complexity, New York, NY: Hampton Press. 
Mouritsen, J. (2006). Problematising intellectual capital research: ostentive versus performative IC. Accounting, Auditing \& Accountability Journal, 19(6), 820-841

Murthy, V. \& Mouritsen, J. (2011). The Performance of Intellectual Capital: Mobilising Relationships Between Intellectual and Financial Capital in a Bank. Accounting, Auditing \& Accountability Journal, 24(5), 622-646.

Nahapiet, J. \& Ghoshal, S. (1998). Social Capital, Intellectual Capital, and the Organizational Advantage. Academy of Management Review, 23(2), 242-266.

Nakao, T. (1993). Market Share, Advertising, R\&D, and Profitability: An Empirical Analysis of Leading Industrial Firms in Japan. Review of Industrial Organization, 8(3), 315-328.

Narver, J.C. \& Slater, S.F. (1990). The Effect of a Market Orientation on Business Profitability. The Journal of Marketing, 54(4), 20-35.

Nelson, R.R. \& Winter, S.G. (1982), An Evolutionary Theory of Economic Change, Cambridge, MA.: Belknap Press of Harvard University Press,

Nohria, N. \& Gulati, R. (1996). Is Slack Good or Bad Innovation? Academy of Management Journal, 39(5), 1245-1264.

O'Sullivan, D. \& McCallig, J. (2012). Customer Satisfaction, Earnings and Firm Value. European Journal of Marketing, 46(6), 827-843.

Ohnemus, L. (2009). Is Branding Creating Shareholder Wealth for Banks? International Journal of Bank Marketing, 27(3), 186-201.

Orlitzky, M., Schmidt, F.L. \& Rynes, S.L. (2003). Corporate Social and Financial Performance: A Meta-analysis. Organization Studies, 24(3), 403-441.

Orsingher, C., Valentini, S. \& de Angelis, M. (2010). A Meta-analysis of Satisfaction with Compliant Handling in Services. Journal of the Academy of Marketing Science, 38(2), 169-186.

Palmatier, R., Dant, R.P., Grewal, D. \& Evans, K.R. (2006). Factors Influencing the Effectiveness of Relationship Marketing: A Meta-analysis. Journal of Marketing, 70(4), 136-153.

Park, C.S. \& Srinivasan, V. (1994). A Survey-based Method for Measuring and Understanding Brand Equity and Its Extendibility. Journal of Marketing Research, 31(2), 271-288.

Penman, S.H. (2009). Accounting for Intangible Assets: There is Also an Income Statement. Abacus, 45(3), 358-371.

Pfeffer, J. (2014). How to Make a Fortune Without "Doing" Anything: The Uber, Airbnb Story. Available at www.fortune.com.

Phusavat, K., Comepa, N., Sitko-Lutek, A. \& Ooi, K.-B. (2011). Interrelationships Between Intellectual Capital and Performance. Industrial Management and Data Systems, 111(6), 810-829.

Ramus, T., Vaccaro, A. \& Brusoni, S. (2017). Institutional Complexity in Turbulent Times: Formalization, Collaboration, and the Emergence of Blended Logics. Academy of Management Journal, 60(4), 1253-1284.
Ray, G., Barney, J.B. \& Muhanna, W.A. (2004). Capabilities, Business Processes, and Competitive Advantage: Choosing the Dependent Variable in Empirical Test of The Resource Based-View. Strategic Management Journal, 25(1), 23-37.

Reed, K.K., Lubatkin, M. \& Srinivasan, N. (2006). Proposing and Testing an Intellectual Capital-based View of the Firm. Journal of Management Studies, 43(4), 867-893.

Rego, L.L., Morgan, N.A. \& Fornell, C. (2013). Reexamining the Market Share-Customer Satisfaction Relationship. Journal of Marketing, 77(5), 1-20.

Robertson, F.A. \& Samy, M. (2015).'Factors Affecting the Diffusion of Integrated Reporting - a UK FTS 100 Perspective. Sustainability Accounting, Management \& Policy Journal, 6(2), 190-223.

Roca-Puig, V., Beltran-Martin, I. \& Segarra-Copres, M. (2011). Combined Effect of Human Capital, Temporary Employment and Organizational Size on Firm Performance. Personnel Review, 41(1), 4-22.

Rosenthal, R. (1978). Combining Results of Independant Studies. Psycological Bulletin, 85(1), 185-193.

Rosenthal, R. (1991), Meta-analytic Procedures for Social Research, Newbury Park, CA: Sage.

Rubera, G. \& Droge, C. (2013). Technology versus Desing Innovation's Effects on Sales and Tobin's Q: The Moderating Role of Branding Strategy. Journal Production Innovation Management, 30(3), 448-464.

Ryals, L. (2005). Making Customer Relationship Management Work: The Measurement and Profitable Management of Customer Relationships. Journal of Marketing, 69(4), 252-261.

Scheer, L., Miao, C. \& Palmatier, R. (2015). Dependence and Interdependence in Marketing Relationships: A Meta-analysis Insights. Journal of the Academy of Marketing Science, 43(6), 694-712.

Sels, L., De Winne, S., Delmotte, J., Maes, J., Faems, D. \& Forrier, A. (2006). Linking HRM and Small Business Performance: An Impact of HRM Intensity on the Productivity and Financial Performance of Small Businesses. Small Business Economics, 26(1), 83-101.

Shankar, V., Azar, P. \& Fuller, M. (2008). BRANEQT: A Multicategory Brand Equity Model and Its Application at Allstate. Marketing Science, 27(4), 567-584.

Shipilov, A. \& Danis, W. (2006). TMG Social Capital Strategic Choice and Firm Performance. European Management Journal, 24(1), 16-27.

Simnett, R. \& Huggins, A.L. (2015). Integrated Reporting and Assurance: Where Can Research Add Value? Sustainability Accounting, Management \& Policy Journal, 6(1), 29-53.

Simon, C.J. \& Sullivan, M.W. (1993). The Measurement and Determinants of Brand Equity: A Financial Approach. Marketing Science, 12(1), 28-52.

Sirmon, D.G., Hitt, M.A., Ireland, R.D. \& Gilbert, B.A. (2011). Resource Orchestration to Create Competitive Advantage: Breadth, Depth, and Life Cycle Effects. Journal of Management, 37(5), 1390-1412. 
Smith, K.T., Smith, M. \& Kun, W. (2010). Does Brand Management of Corporate Reputation Translate Into Higher Market Value? Journal of Strategic Marketing, 18(3), 201-221.

Smith, R.E. \& Wright, W.F. (2004). Determinants of Customer Loyalty and Financial Performance. Journal of Management Accounting Research, 16(1), 183-205.

Stanley, T.D. (2001). Wheat from Chaff: Meta-analysis as Quantitative Literature Review. Journal of Economics Perspectives, 15(3), 131-150.

Steel, P.D. \& Kammeyer-Mueller, J.D. (2002). Comparing Meta-analytic Moderator Estimation Techniques Under Realistic Conditions. Journal of Applied Psychology, 87(1), 96-111.

Subramaniam, M. \& Youndt, M.A. (2005). The Influence of Intellectual Capital on the Types of Innovative Capabilities. Academy of Management Journal, 48(3), 450-463.

Szymanski, D.M. \& Henard, D.H. (2001). Customer Satisfaction: A Meta-analysis of the Empirical Evidence. Journal of the Academy of Marketing Science, 29(1), 16-36.

Szymanski, D.M., Kroff, M.W. \& Troy, L.C. (2007). Innovativeness and New Product Success: Insights from the Cumulative Evidence. Journal of the Academy of Marketing Science, 35(1), 35-52.

Teece, D.J. (2000), Managing Intellectual Capital, New York, NY: Oxford University Press.

Tharenou, P., Saks, A.M. \& Moore, C. (2007). A Review and Critique of Research on Training and Organizational-level Outcomes. Human Resource Management Review, 17(3), 251-273.

Thomson, M., MacInnis, D.J. \& Park, C.W. (2005). The Ties That Bind: Measuring the Strength of Consumers' Emotional Attachments to Brands. Journal of Consumer Psychology, 15(1), 77-91.

Van Alstyne, M.W., Parker, G.G. \& Choudary, S.P. (2016). Pipelines, Platforms, and the New Rules of Strategy. Harvard Business Review, 94(4), 16-25.

Villalonga, B. (2004). Intangible Resources, Tobin's q, and Sustainability of Performance Differences. Journal of Economic Behavior \& Organization, 54(2), 205-230.

Von Nordenflycht, A. (2010). What is a Professional Service Firm? Toward a Theory and Taxonomy of Knowledge-intensive Firms. Academy of Management Review, 35(1), 155-174.

Whitener, E.M. (1990). Confusion of Confidence Intervals and Credibility Intervals in Meta-Analysis. Journal of Applied Psychology, 75(3), 315-321.

Winter, S.G. (2003). Understanding Dynamic Capabilities. Strategic Management Journal, 24(10), 991-995.

Wolf, F.M. (1986), Meta-Analysis: Quantitative Methods for Research Synthesis, Sage University Paper, 59. Newbury Park, CA: Sage Publications.
Wyatt, A. (2008). What Financial and Non-financial Information on Intangibles is Value-relevant? a Review of Evidence. Accounting and Business Research, 38(3), 217-256.

Yarbrough, L., Morgan, N.A. \& Vorhies, D.W. (2011). The Impact of Product Market Strategyorganizational Culture Fit on Business Performance. Journal of the Academy of Marketing Science, 39(4), 555-573.

Yeung, M.C. \& Ennew, C.T. (2000). From Customer Satisfaction to Profitability. Journal of Strategic Marketing, 8(4), 313-326.

Youndt, M.A., Subramaniam, M. \& Snell, S.A. (2004). Intellectual Capital Profiles: an Examination of Investments and Returns. Journal of Management Studies, 41(2), 335-362.

Yuqian, H. \& Dayuan, L. (2015). Effects of Intellectual Capital on Innovative Performance. Management Decision, 53(1), 40-56.

Ziliak, S.T. \& McCloskey, D.N. (2008), The Cult of Statistical Significance. How the Standard Error Costs Us Jobs, Justice, and Lives, Ann Arbor, MI: University of Michigan Press. 


\section{List of references included in the meta-analysis}

* Aaker, D.A. \& Jacobson, R. (1994). The Financial Information Content of Perceived Quality. Journal of Marketing Research, 31(2), 191-201.

* Anderson, E.W., Fornell, C. \& Lehmann, D.R. (1994). Customer Satisfaction, Market Share, and Profitability: Findings From Sweden. Journal of Marketing, 58(3), 53-66.

* Anderson, E.W., Fornell, C. \& Rust, R.T. (1997). Customer Satisfaction, Productivity, and Profitability: Differences Between Goods and Services. Marketing Science, 16(2), 129-145.

* Anderson, E.W., Fornell, C. \& Mazvancheryl, S.K. (2004). Customer Satisfaction and Shareholder Value. Journal of Marketing, 68(4), 172-185.

* Andreou, A.N. \& Bontis, N. (2007). A Model for Resource Allocation Using Operational Knowledge Assets. The Learning Organization, 14(4), 345-374.

* Angulo-Ruiz, F., Donthu, N., Prior, D. \& Rialp, J. (2014). The Financial Contribution of Customeroriented Marketing Capability. Journal of the Academy of Marketing Science, 42(4), 380-399.

* Aragon-Sanchez, A., Barba-Aragon, I. \& Sanze-Valle, R. (2003). Effects of Training on Business Results. International Journal of Human Resource Management, 14(6), 956-980.

* Artz, K.W., Norman, P.M., Hatfield, D.E. \& Cardinal, L.B. (2010). A Longitudinal Study of the Impact of R\&D, Patents, and Product Innovation on Firm Performance. Journal of Product Innovation Management, 27(5), 725-740.

* Asiaei, K. \& Jusoh, R., (2015). A Multidimensional View of Intellectual Capital: The Impact on Organizational Performance. Management Decision, 53(3), 668-697.

* Barth, M.E., Clement, M.B., Foster, G. \& Kasznik, R. (1998). Brand Values and Capital Market Valuation. Review of Accounting Studies, 3(1-2), 41-68.

* Bharadwaj, A.S., Bharadwaj, S.G. \& Konsynski, B.R. (1999). Information Technology Effects on Firm Performance as Measured by Tobin's q. Management Science, 45(7), 1008-1024.

* Camisón, C. \& Villar-López, A. (2010). Effect of SMEs' International Experience on Foreign Intensity and Economic Performance: The Mediating Role of Internationally Exploitable Assets and Competitive Strategy. Journal of Small Business Management, 48(2), 116-151.

* Chin, C.L., Lee, P., Chi, H.Y. \& Anandarajan, A. (2006). Patent Citation, R\&D Spillover, and Tobin's Q: Evidence from Taiwan Semiconductor Industry. Review of Quantitative Finance and Accounting, 26(1), 67-84.

* Cho, H.J. \& Pucik, V. (2005). Relationship Between Innovativeness, Quality, Growth, Profitability, and Market Value. Strategic Management Journal, 26(6), 555-575.

* Coombs, J.E. \& Bierly, P.E. (2006). Measuring Technological Capability and Performance. R\&D Management, 36(4), 421-438.
* Coviello, N., Winklhofer, H. \& Hamilton, K. (2006). Marketing Practices and Performance of Small Service Firms: An Examination in the Tourism Accommodation Sector. Journal of Service Research, 9(1), 38-58.

* Davies, G., Chun, R. \& Kamins, M.A. (2010). Reputation Gaps and the Performance of Service Organizations. Strategic Management Journal, 31(5), 530-546.

* Dibrell, C., Davis, P.S. \& Craig, J. (2008). Fueling Innovation Through Information Technology in SMEs. Journal of Small Business Management, 46(2), 203-218.

* do Rosario-Cabrita, M. \& Bontis, N. (2008). Intellectual Capital and Business Performance in the Portuguese Banking Industry. International Journal of Technology Management, 43(1-3), 212-237.

* Duncan, E. \& Elliott, G. (2004). Efficiency, Customer Service and Financial Performance Among Australian Financial Institutions. International Journal of Bank Marketing, 22(5), 319-342.

* Eggers, F., Kraus, S., Hughes, M., Laraway, S. \& Snycerski, S. (2013). Implications of Customer and Entrepreneurial Orientations for SME Growth. Management Decision, 51(3), 524-546.

* Ettlie, J.E. (1998). R\&D and Global Manufacturing Performance. Management Science, 44(1), 1-11.

* Fehle, F., Fournier, S.M., Madden, T.J. \& Shrider, D.G. (2008). Brand Value and Asset Pricing. Quarterly Journal of Finance and Accounting, 47(1), 3-26.

* Fornell, C., Mithas, S., Morgeson III, F.V. \& Krishnan, M.S. (2006). Customer Satisfaction and Stock Prices: High Returns, Low Risk. Journal of Marketing, 70(1), 3-14.

* Gruca, T.S. \& Rego, L.L. (2005). Customer Satisfaction, Cash Flow, and Shareholder Value. Journal of Marketing, 69(3), 1-130.

* Guo, W.C., Shiah-Hou, S.R. \& Chien, W.J. (2012). A Study on Intellectual Capital and Firm Performance in Biotech Companies. Applied Economics Letters, 19(16), 1603-1608.

* Harrison, J.S., Hall, E.H. \& Nargundkar, R. (1993). Resource Allocation as an Outcropping of Strategic Consistency: Performance Implications. Academy of Management Journal, 36(5), 1026-1051.

* Heiens, R.A., Leach, R.T. \& McGrath, L.C. (2007). The Contribution of Intangible Assets and Expenditures to Shareholder Value. Journal of Strategic Marketing, 15(2-3), 149-159.

* Holbrook, M.B. (1992). Product Quality, Attributes, and Brand Name as Determinants of Price: The Case of Consumer Electronics. Marketing Letters, 3(1), 71-83.

* Hooley, G.J., Greenley, G.E., Cadogan, J.W. \& Fahy, J. (2005). The Performance Impact of Marketing Resources. Journal of Business Research, 58(1), 18-27.

* Hsu, L.C. \& Wang, C.H. (2012). Clarifying the Effect of Intellectual Capital on Performance: The Mediating Role of Dynamic Capability. British Journal of Management, 23(2), 179-205. 
* Jha, S., Balaji, M.S., Yavas, U. \& Babakus, E. (2017). Effects of Frontline Employee Role Overload on Customer Responses and Sales Performance. European Journal of Marketing, 51(2), 282-303.

* Juma, N. \& Payne, G.T. (2004). Intellectual Capital and Performance of New Venture High-tech Firms. International Journal of Innovation Management, 8(3), 297-318.

* Kamakura, W.A., Mittal, V., De Rosa, F. \& Mazzon, J.A. (2002). Assessing the Service-Profit Chain. Marketing Science, 21(3), 294-317.

* Kambara, K.M. (2010). Managing Brand Instability and Capital Market Reputation: Implications for Brand Governance and Marketing Strategy. Journal of Brand Management, 17(8), 568-578.

* Kim, H., Lim, H. \& Park, Y. (2009). How Should Firms Carry Out Technological Diversification to Improve Their Performance? An Analysis of Patenting of Korean Firms. Economics of Innovation and New Technology, 18(8), 757-770.

* Kirk, C.P., Ray, I. \& Wilson, B.K. (2013). The Impact of Brand Value on Firm Valuation: The Moderating Influence of Firm Type. Journal of Brand Management, 20(6), 488-500.

* Krasnikov, A., Mishra, S. \& Orozco, D. (2009). Evaluating the Financial Impact of Branding Using Trademarks: A Framework and Empirical Evidence. Journal of Marketing, 73(6), 154-166.

* Lin, B.W., Lee, Y. \& Hung, S.C. (2006). R\&D Intensity and Commercialization Orientation Effects on Financial Performance. Journal of Business Research, 59(6), 679-685.

* Lin, B.W., Chen, C.J. \& Wu, H.L. (2006). Patent Portfolio Diversity, Technology Strategy, and Firm Value. IEEE Transactions on Engineering Management, 53(1), 17-26.

* Ling, Y.-H. \& Jaw, B.-S. (2006). The Influence of International Human Capital on Global Initiatives and Financial Performance. International Journal of Human Resource Management, 17(3), 379-398.

* Livne, G., Simpson, A. \& Talmor, E. (2011). Do Customer Acquisition Cost, Retention and Usage Matter to Firm Performance and Valuation? Journal of Business Finance \& Accounting, 38(3-4), 334-363.

* Luo, X., Griffith, D.A., Liu, S.S. \& Shi, Y.Z. (2004). The Effects of Customer Relationships and Social Capital on Firm Performance: A Chinese Business Illustration. Journal of International Marketing, 12(4), 25-45.

* Matsuno, K., Zhu, Z. \& Rice, M.P. (2014). Innovation Process and Outcomes for Large Japanese Firms: Roles of Entrepreneurial Proclivity and Customer Equity. Journal of Product Innovation Management, 31(5), 1106-1124.

* Matzler, K., Hinterhuber, H.H., Daxer, C. \& Huber, M. (2005). The Relationship Between Customer Satisfaction and Shareholder Value. Total Quality Management, 16(5), 671-680.

* McAlister, L., Srinivasan, R. \& Kim, M. (2007). Advertising, Research and Development, and Systematic Risk of the Firm. Journal of Marketing, 71(1), 35-48.
* Minami, C. \& Dawson, J. (2008). The CRM Process in Retail and Service Sector Firms in Japan: Loyalty Development and Financial Return. Journal of Retailing and Consumer Services, 15(5), 375-385.

* Mizik, N. \& Jacobson, R. (2008). The Financial Value Impact of Perceptual Brand Attributes. Journal of Marketing Research, 45(1), 15-32.

* Mizik, N. \& Jacobson, R. (2009). Valuing Branded Businesses. Journal of Marketing, 73(6), 137-153.

* Morgan, N.A. \& Rego, L.L. (2009). Brand Portfolio Strategy and Firm Performance. Journal of Marketing, 73(1), 59-74.

* Nakao, T. (1993). Market Share, Advertising, R\&D, and Profitability: An Empirical Analysis of Leading Industrial Firms in Japan. Review of Industrial Organization, 8(3), 315-328.

* Nybakk, E. (2012). Learning Orientation, Innovativeness and Financial Performance in Traditional Manufacturing Firms: A Higher-order Structural Equation Model. International Journal of Innovation Management, 16(05), 1250029.

* OSullivan, D. \& McCallig, J. (2012). Customer Satisfaction, Earnings and Firm Value. European Journal of Marketing, 46(6), 827-843.

* Ohnemus, L. (2009). Is Branding Creating Shareholder Wealth for Banks? International Journal of Bank Marketing, 27(3), 186-201.

* Phusavat, K., Comepa, N., Sitko-Lutek, A. \& Ooi, K.B. (2011). Interrelationships Between Intellectual Capital and Performance. Industrial Management and Data Systems, 111(6), 810-829.

* Reed, K.K., Lubatkin, M. \& Srinivasan, N. (2006). Proposing and Testing an Intellectual Capital-based View of the Firm. Journal of Management Studies, 43(4), 867-893.

* Rego, L.L., Morgan, N.A. \& Fornell, C. (2013). Reexamining the Market Share-Customer Satisfaction Relationship. Journal of Marketing, 77(5), 1-20.

* Roca-Puig, V., Beltrán-Martín, I. \& Segarra Cipres, M. (2011). Combined Effect of Human Capital, Temporary Employment and Organizational Size on Firm Performance. Personnel Review, 41(1), 4-22.

* Rubera, G. \& Droge, C. (2013). Technology Versus Design Innovations Effects on Sales and Tobins Q: The Moderating Role of Branding Strategy. Journal of Production Innovation Management, 30(3), 448-464.

* Salomo, S., Talke, K. \& Strecker, N. (2008). Innovation Field Orientation and its Effect on Innovativeness and Firm Performance. Journal of Product Innovation Management, 25(6), 560-576.

* Santos-Vijande, M.L., González-Mieres, C. \& Ángel López-Sánchez, J. (2013). An Assessment of Innovativeness in KIBS: Implications on KIBS' CoCreation Culture, Innovation Capability, and Performance. Journal of Business \& Industrial Marketing, 28(2), 86-102.

* Sels, L., De Winne, S., Delmotte, J., Maes, J., Faems, D. \& Forrier, A. (2006). Linking HRM and Small Business Performance: An Impact of HRM Intensity on the Productivity and Financial Performance of Small Businesses. Small Business Economics, 26(1), 83-101. 
* Smith, K.T., Smith, M. \& Kun, W. (2010). Does Brand Management of Corporate Reputation Translate Into Higher Market Value? Journal of Strategic Marketing, 18(3), 201-221.

* Smith, R.E. \& Wright, W.F. (2004). Determinants of Customer Loyalty and Financial Performance. Journal of Management Accounting Research, 16(1), 183-205.

* Soni, P.K., Lilien, G.L. \& Wilson, D.T. (1993). Industrial Innovation and Firm Performance: A Reconceptualization and Exploratory Structural Equation Analysis. International Journal of Research in Marketing, 10(4), 365-380.

* Stanko, M.A. \& Bonner, J.M. (2013). Projective Customer Competence: Projecting Future Customer Needs That Drive Innovation Performance. Industrial Marketing Management, 42(8), 1255-1265.

* Tavassoli, N.T., Sorescu, A. \& Chandy, R. (2014). Employee-based Brand Equity: Why Firms with Strong Brands Pay Their Executives Less. Journal of Marketing Research, 51(6), 676-690.

* Thomson, M., Maclnnis, D.J. \& Park, C.W. (2005). The Ties That Bind: Measuring the Strength of Consumers' Emotional Attachments to Brands. Journal of Consumer Psychology, 15(1), 77-91.
* Tseng, K.A., Lan, Y.W., Lu, H.C. \& Chen, P.Y. (2013). Mediation of Strategy on Intellectual Capital and Performance. Management Decision, 51(7), 1488-1509.

* Wang, Z., Wang, N. \& Liang, H. (2014). Knowledge Sharing, Intellectual Capital and Firm Performance. Management Decision, 52(3), 230-258.

* Worm, S. \& Srivastava, R.K. (2014). Impact of Component Supplier Branding on Profitability. International Journal of Research in Marketing, 31(4), 409-424.

* Yee, R.W.Y., Yeung, A.C.L. \& Chen, T.C.E. (2010). An Empirical Study of Employee Loyalty, Service Quality and Firm Performance in the Service Industry. International Journal of Production Economics, 124(1), 109-120.

* Yeung, M.C. \& Ennew, C.T. (2000). From Customer Satisfaction to Profitability. Journal of Strategic Marketing, 8(4), 313-336.

* Youngsang, K. \& Ployhart, R.E. (2014). The Effects of Staffing and Training on Firm Productivity and Profit Growth Before, During, and After the Great Recession. Journal of Applied Psychology, 99(3), 361-389.

* Zhang, R. \& Rezaee, Z. (2009). Do Credible Firms Perform Better in Emerging Markets? Evidence from China. Journal of Business Ethics, 90(2), 221-237

Elisabeth Albertini is an Associate Professor at the Sorbonne Business School (University of Paris 1 Pantheon-Sorbonne), teaching corporate social responsibility and accounting. Her research interests include corporate social responsibility from a resource-based perspective; intellectual capital; extra-financial disclosure and integrated reporting. Prior to academia, she worked for the Xerox Company as a Corporate Financial Planning \&Accounting Manager.

Fabienne Berger-Remy is Associate Professor in Brand Management at the Sorbonne Business School (University of Paris 1 Pantheon-Sorbonne), France. Her research deals with intellectual capital, marketing organizations and formal or informal processes in brand management. She previously worked for twenty years in the Fast Moving Consumer Goods sector in a range of roles spanning marketing, consulting and management.

Acknowledgments: We express our deep gratitude to Dr Thomas Roulet and two anonymous reviewers for significant help and guidance in improving the manuscript. 